\title{
THE CHOICE BETWEEN AUDIT AND CONSULTING SERVICES IN THE POST- SOX ENVIRONMENT
}

\author{
by \\ Ronen Gal-Or \\ A Dissertation Submitted to the Faculty of the \\ Committee on Business Administration \\ In Partial Fulfillment of the Requirements \\ For the Degree of \\ DOCTOR OF PHILOSOPHY \\ WITH A MAJOR IN MANAGEMENT \\ In the Graduate College \\ THE UNIVERSITY OF ARIZONA
}




\section{THE UNIVERSITY OF ARIZONA GRADUATE COLLEGE}

As members of the Dissertation Committee, we certify that we have read the dissertation prepared by Ronen Gal-Or

entitled The Choice Between Audit and Consulting Services in the Post-SOX Environment and recommend that it be accepted as fulfilling the dissertation requirement for the Degree of Doctor of Philosophy

Date: $4 / 27 / 2011$

Dan Dhaliwal

Date: 4/27/2011

William Waller

Date: $4 / 27 / 2011$

Kirsten Cook

Final approval and acceptance of this dissertation is contingent upon the candidate's submission of the final copies of the dissertation to the Graduate College.

I hereby certify that I have read this dissertation prepared under my direction and recommend that it be accepted as fulfilling the dissertation requirement.

Date: $4 / 27 / 2011$

Dissertation Director: Dan Dhaliwal 


\section{STATEMENT BY AUTHOR}

This dissertation has been submitted in partial fulfillment of requirements for an advanced degree at the University of Arizona and is deposited in the University Library to be made available to borrowers under rules of the Library.

Brief quotations from this dissertation are allowable without special permission, provided that accurate acknowledgment of source is made. Requests for permission for extended quotation from or reproduction of this manuscript in whole or in part may be granted by the head of the major department or the Dean of the Graduate College when in his or her judgment the proposed use of the material is in the interests of scholarship. In all other instances, however, permission must be obtained from the author.

SIGNED: Ronen Gal-Or 


\section{ACKOWLEDGEMENTS}

I am grateful for the helpful support and guidance of my committee members: Dan Dhaliwal (co-chair), William Felix (co-chair), William Waller, and Kirsten Cook. This paper has also benefited from the helpful comments and suggestions of John Campbell, Dane Christensen, James Chyz, Phil Lamoreaux, Landon Mauler, Logan Steele, and workshop participants at the University of Arizona, Temple University, Pennsylvania State University, Indiana University, University of Tennessee, University of Texas Dallas, University of Alberta, University of Waterloo, Northeastern University, McGill University, University of Massachusetts - Amherst, and the College of William and Mary. 
TABLE OF CONTENTS

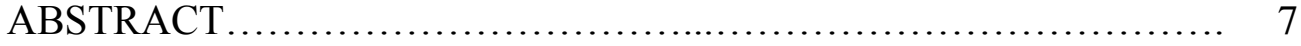

1. INTRODUCTION ................................................ 8

2. LITERATURE REVIEW AND HYPOTHESIS DEVELOPMENT..... 13

2.1 Auditor Switches Following the Mandated Separation of Auditing and Consulting Services....................................... 13

2.2 Auditor Industry Specialization................................. 14

2.3 Historical Dependence of the Audit Firm to Provide Consulting Services................................................... 17

2.4 Likelihood That the Client Will Procure Consulting Services in the Future...................................................... 18

2.5 The Effect of Choosing Consulting on Audit Fees and Quality................................................. 24

3. EMPIRICAL RESEARCH DESIGN ........................... 27

3.1 Testing the Influence of Auditor Industry Specialization and the Historical Level of Auditor-Provided Consulting Fees on Auditor Switch Decisions (H1 and H2)....

3.2 Testing the Influence of the Historical Level of Auditor-Provided Consulting Fees Interacted with the Likelihood the Client Will Require Consulting Services in the Future on Auditor Switch Decisions (H3) .......................................... 34

3.3 Testing the Efficiency Losses resulting from Deloitte's Independence-Induced Auditor Switches (H4).................. 36

3.4 Testing the Loss of Audit Quality resulting from Deloitte's Independence-Induced Auditor Switches (H5)................. 38

4. SAMPLE SELECTION ....................................... 41

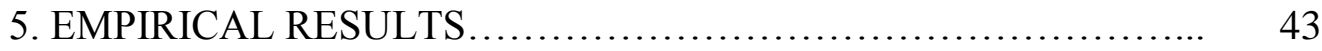

5.1 Descriptive Statistics - Model (1)........................... 43

5.2 Multivariate Analyses - Model (1) - Factors Influencing the Choice Between Auditing and Consulting....................... 45

5.3 Multivariate Analyses - Model (2) - Loss of Audit Efficiency.... $\quad 50$

5.4 Multivariate Analyses - Loss of Audit Quality.................... 53

6. ROBUSTNESS TESTS AND ADDITIONAL ANALYSIS............ 54

6.1 Alternative Auditor Industry Specialization Measures.............. 54

6.2 Alternative Consulting Likelihood Measures...................... 55

6.3 Alternate Control Sample...................................... 57

7. CONCLUSION ................................................. 58

APPENDIX A. TIMELINE OF CONSULTING DIVISION

SPINOFFS ..................................... 60 


\section{TABLE OF CONTENTS - Continued}

APPENDIX B. EXAMPLES OF DELOITTE AUDITOR SWITCHES

INDUCED BY THE JOINT AUDITOR-CLIENT

DECISION TO CONTINUE THE CONSULTING

RELATIONSHIP ............................... 61

APPENDIX C. VARIABLE DEFINITIONS........................ 62

APPENDIX D. CONTROL VARIABLE INCLUSION RATIONALE. $\quad 64$

APPENDIX E. TABLES ........................................... 70

REFERENCES .................................................. 80 


\begin{abstract}
I examine factors influencing accounting firms' and their clients' decisions to pursue an auditing vs. consulting relationship. I employ the Sarbanes Oxley Act (SOX) prohibition on providing both services to the same clients as a natural experiment. Because Deloitte $\&$ Touche was the only Big 4 firm to retain its consulting division post-SOX, I compare Deloitte's client switch and retention decisions to those made by its direct competitors. In this context, I investigate how the decision to continue or terminate an audit relationship is influenced by auditor industry specialization, the historical provision of auditor-provided consulting services and the likelihood that the client will require consulting services in the future. I find that there is a preference for auditing when the auditor is a specialist in the client's industry, and there is a preference for consulting when the auditor-provided consulting services in the past and the client is likely to require consulting services in the future. I also report empirical evidence on audit effectiveness and efficiency in cases where the auditor and its client discontinued the audit in order to maintain a consulting relationship. Although there was no impact on audit effectiveness, the auditor switches reduced efficiency as evidenced by significantly higher audit fees. This study is relevant to the current audit environment because public accounting firms that spun-off their consulting divisions around the enactment of SOX are in the process of rebuilding their consulting practices and must now choose between providing audit and consulting services to their clients. It may also be pertinent to European policy makers who are currently considering a proposal to limit auditors' ability to jointly offer audit and consulting services to the same client.
\end{abstract}




\section{INTRODUCTION}

In this study, I examine a large professional services firm's adaptation to the U.S. government's intervention into the market for audit and consulting services. Throughout the 1980s and 1990s, large firms expanded their product line to include many consulting services in addition to auditing and tax services. By the mid-1990s, firms such as Deloitte \& Touche (Deloitte), PricewaterhouseCoopers (PwC), Ernst \& Young (EY), Arthur Andersen (AA), and KPMG, were earning more than 50 percent of total revenue from non-audit services (GAO, 2003). In many cases, the firms provided both audit and non-audit services to the same client. The joint provision of audit and non-audit services raised concern about whether the firms' auditors were independent in fact and appearance. The most vocal critic was SEC Chair, Arthur Levitt, who advocated restrictions on the joint provision of audit and non-audit services (Levitt, 2000). This market trend reversed in the late 1990s and early 2000s when AA, EY, PwC, and KPMG sold their consulting divisions (see Appendix A for a timeline of these consulting division spinoffs), and signed non-compete agreements with the acquirers. Although each divestiture was a market-mediated transaction, it is likely that increasing concern about auditor independence was a contributing factor. In the aftermath of AA's audit failures at Enron and WorldCom, the U.S. government enacted the Sarbanes-Oxley Act (SOX) in 2002. In line with Levitt's viewpoint, Section 201 of SOX prohibited auditors from providing most types of non-audit services contemporaneously with the audit of public clients (US Congress, 2002). Given the divestitures noted above, I interpret Section 201 
as a governmental intervention in the ongoing market process of re-organizing audit and consulting services.

Deloitte was the only large public accounting firm to retain its consulting division. ${ }^{1}$ To comply with the independence rules in SOX, it was necessary for decision makers at Deloitte and its clients to choose between audit and consulting services. My personal communication with a Deloitte managing partner suggests that these case-bycase decisions were driven by value-added considerations. Deloitte typically identified and proposed to supply the type of service that produced the most value for the client. Based on its own analysis, the client accepted or rejected Deloitte's proposal. I conjecture that these decisions about audit versus consulting services factored into auditor switches involving Deloitte in the post-SOX period.

The main purpose of my study is to contribute empirical evidence that helps to explain Deloitte's auditor switches in terms of three factors. First, I predict and find that Deloitte continued to provide audit rather than consulting services when the firm was an industry specialist with respect to the client. Second, I predict and find that Deloitte continued to provide consulting rather than audit services for clients that historically procured high-levels of auditor-provided consulting services. Third, I predict and find that Deloitte continued to provide consulting rather than audit services for joint service clients $^{2}$ that were likely to require consulting services in the future. I proxy for future consulting requirements by capturing the client's (1) free cash flow, (2) M\&A activity,

\footnotetext{
${ }^{1}$ Reports in the business press indicated that Deloitte was in negotiation to sell its consulting division but ultimately decided against the sale (Byrnes, 2003).

${ }^{2}$ Joint-service clients refer to clients that procured both audit and consulting services from their external auditor before the enactment of SOX.
} 
(3) Debt and Equity Issuance Activity, and (4) growth opportunities. My tests include data from EY, PwC, and KPMG, as a control group.

In addition to identifying factors influencing the choice between audit and consulting, I also examine whether the decision to discontinue the audit and maintain a consulting relationship influences audit effectiveness and efficiency. The forced auditor switch which occurred when Deloitte and its joint service client chose consulting might have led to the selection of an inferior successor auditor in terms of effectiveness and efficiency. I report empirical evidence on changes in audit effectiveness and efficiency for cases in which Deloitte no longer provided audit services. Although there was no impact on audit effectiveness, I predict and find that Deloitte's independence-induced auditor switches reduced efficiency as evidenced by significantly higher audit fees. ${ }^{3}$

Prior studies investigating the joint provision of audit and non-audit services and the influence of the mandated separation of such services concentrate on answering the following two questions. First, was the prohibition on providing audit and non audit services (including consulting services) necessary to ensure audit and financial reporting quality (Frankel et al, 2002; Defond et al, 2002; Chung et al, 2003, Kinney et al, 2004, Kornish et al, 2004; Lim and Tan, 2008)? Second, did the prohibition have its intended effect of improving actual or perceived audit and financial reporting quality (Chambers et al, 2008)? While much of this literature examines the necessity and influence of the SOX

\footnotetext{
${ }^{3}$ I use audit fees to proxy for audit efficiency in lieu of more direct measures such as labor costs (Knechel et al. 2009), and labor allocation (Bell et al, 2008), because these latter measures are not publically available. Prior research suggests that audit efficiency is highly correlated with unexpected audit fees (Knechel et al. 2009). Thus, the costs associated with decreased efficiency are at least partially passed onto the client in the form of higher fees.
} 
non-audit service prohibitions in regards to audit quality, my paper is the first to investigate the client realignment and audit fee changes induced by these prohibitions.

In addition to systematically examining one large firm's immediate adaptation to Section 201 of SOX, my study is relevant to current research and regulation. Given the lapse of non-compete agreements ${ }^{4}$, other large firms are dramatically increasing their investment in consulting ${ }^{5}$. Moreover, the current market is characterized by thinning margins in audit pricing which has encouraged accounting firms to search for alternative sources of income in more high-margin sectors (including consulting). All Big Four public accounting firms now face the recurring decision of whether to provide audit or consulting services to a given client. My study provides a baseline for examining these decisions. Although the current environment does not mirror the environment immediately following the enactment of SOX, the firm and engagement-specific determinants identified in this paper may help researchers identify auditor switches that are driven by the decision to continue the consulting rather than the audit relationship. Future research can assess the extent to which the factors identified in this paper remain important in recent auditor-client realignment decisions.

Regarding regulation, the European Union (EU) recently aired a proposal that would limit the ability of European auditors to jointly provide audit and consulting services to the same client (EU, 2010). Although this proposal is still in negotiation, in

\footnotetext{
${ }^{4}$ Ernst \& Young's non-compete agreement with Cap Gemini expired in May 2005, KPMG's non-compete agreement with BearingPoint expired in August 2006, and PwC's non-compete agreement with IBM expired in October 2007.

${ }^{5}$ According to Business Week, in 2006 KPMG sold $\$ 5.3$ billion in consulting services, a $12 \%$ jump from the year before. PWC sold $\$ 3.7$ billion, a $20 \%$ increase, and E\&Y sold \$2.4 billion, a $2 \%$ increase (Byrnes, 2007). A recent study by the Department of the Treasury provided evidence that the rate of growth for non-audit services, especially advisory services offered to non-audit clients, now exceeds the rate of growth for audit services (Treasury Department, Advisory Committee on the Auditing Profession, 2008). PWC has been the most active in growing their consulting business over the past two years. In March 2009, PWC revealed their desire to purchase a large portion of BearingPoint's consulting business, and in August 2010, PWC acquired Diamond Management \& Technology Consultants Inc. for $\$ 378$ million.
} 
its current form it would closely mimic the provisions of Section 201 of SOX. In the US, the Treasury Department Advisory Committee suggested to the PCAOB that "an 'audit only firm' may be a more appropriate business model for the profession than the current model which combines the federally and state regulated auditing function that serves the investing public, with the non regulated consulting services" (Treasury, 2008). The Treasury report suggests that accounting firms should concentrate on providing effective and efficient audit services, rather than primarily concentrate on revenue growth ${ }^{6}$. Before the PCAOB or the European Commission consider proposals that further limit the types of services public accounting firms provide, it is important to first understand the effects of prior restrictions imposed on the dual provision of audit and consulting services. My paper is a good starting point for further research investigating the relationship between audit quality/auditor independence and the imposition of such restrictions.

The remainder of the paper is organized as follows. Section 2 reviews the related literature and develops the hypotheses. Section 3 discusses the research design. Section 4 discusses the sample. Section 5 presents the empirical results. Section 6 describes the additional analyses and robustness checks. Finally, section 7 concludes the paper.

\footnotetext{
${ }^{6}$ Authur Wyatt echoes this sentiment in a manuscript describing why the provisions of SOX are insufficient to change the culture of primarily advocating revenue growth even when that growth may impact the firm's reputation for outstanding professionalism in the delivery of its services (Wyatt, 2004).
} 


\section{LITERATURE REVIEW AND HYPOTHESIS DEVELOPMENT}

\subsection{Auditor Switches Following the Mandated Separation of Auditing and Consulting} Services

Although this paper examines a relatively unexplored area of research, it contributes to literature concerning the determinants of post-SOX auditor switches. Prior studies have investigated the reshuffling of audit clients as a result of the indictment of Arthur Andersen (Blouin et al., 2007; Kohlbeck et al., 2008; Ballas et al., 2008, Landsman et al., 2009), and the increase in market contestability as evidenced by the increased use of lower tier (Non-Big 4) auditors (Sullivan, 2006; Rama and Read, 2006; Ettredge et al., 2007; Doogar et al., 2008; Krishnan et al., 2008; Landsman et al., 2009; Hogan et al., 2009). Other papers have identified various firm, auditor and engagement characteristics (such as internal control weaknesses, audit fees, auditor industry specialization, and poor accrual quality) that influenced the likelihood of Post-SOX auditor switches (Ettredge et al., 2007; Nagy et al., 2008; Krishnan et al., 2010). My study adds to this stream of literature by introducing another factor affecting the types of auditor switches occurring post-SOX, i.e. switches induced by the decision to continue a consulting rather than an audit relationship.

I first attempt to identify auditor, firm and engagement factors that influence whether a joint service client will choose audit or consulting services after the mandated separation between the two. Predicting which client will choose which service is difficult, however, because factors which increase the demand, profitability and "goodness of fit" for one type of service may also increase demand for the other. Indeed, 
prior papers provide evidence that before SOX, audit and non-audit fees were simultaneously and endogenously determined based on factors such as agency costs, complexity of operations, size, risk, performance, and auditor characteristics (Whisenant et al., 2003, Antle et al., 2006). After the mandated separation between audit and consulting services in 2002, accounting firms and their clients likely considered these, and other, factors when deciding which service to maintain. I examine three determinants which likely influenced their decision: (1) auditor industry specialization, (2) the historical procurement of consulting services from the auditor, and (3) the likelihood the client will desire consulting services in the future.

I examine these factors from the perspective of the auditor switch decision. When a client is a relatively better candidate for audit services, I predict a lower likelihood of auditor switch. Conversely, when a client is a relatively better candidate for consulting services, I predict a higher likelihood of auditor switch. First, I consider the independent effect of the first two determinants. Then, I examine the interactive relationship between the second and third factors, because the decision to continue the consulting rather than the audit relationship likely depends on the historical procurement of consulting services coupled with future expected consulting requirements.

\subsection{Auditor Industry Specialization}

One factor that may lead auditors and their clients to favor audit over consulting services is auditor quality. If the quality of service provided by the current auditor cannot be maintained by a successor, then the client will be less likely to switch auditors. Recent literature has identified industry specialization as a key determinant of auditor quality. 
Craswell et al. (1995) and Francis et al. (2005) provide evidence that clients are willing to pay a fee premium for audits provided by industry specialists in the Australian and US audit markets, respectively. Some researchers have posited that this premium derives from the differentiated actual and perceived quality of services provided by industry specialists. In support of this conjecture, Balsam et al. (2003) finds that clients of industry specialists exhibit higher earnings quality (evidenced through lower discretionary accruals). Moreover, investors recognize this improved quality by weighting the information content of earnings more heavily as they revise the economic value created or lost during the period (evidenced through higher ERCs). Knechel et al. (2007) provide further evidence that investors value the quality of service provided by industry specialists. They find that investors react positively when there is an auditor switch and the successor auditor is an industry specialist, but react negatively when the successor auditor is not an industry specialist. Dunn et al. (2004) provide evidence that the actual quality of service is not only reflected in improved earnings quality, but also in financial statement disclosure quality. They find a significant positive relationship between industry specialization and disclosure ratings. Lou et al. (2009) and Ahmed et al. (2008) find that auditor industry specialization is associated with lower accounting information risk as evidenced by lower cost of debt and cost of equity, respectively. This suggests that industry specialist auditors help reduce information asymmetries by producing in conjunction with their clients more informative and reliable financial statements. Finally, Nagy et al. (2008) provide evidence that industry specialist auditors 
are less likely than non-specialist auditors to resign from audit engagements after the enactment of SOX.

Based on these findings, I conjecture that the decision to provide audit rather than consulting services after the enactment of SOX is positively related to whether the auditor is an industry specialist. The relation between industry specialization and the audit vs. consulting decision should only apply to firms with the capability to provide both services to their clients. Among the Big 4 firms, Deloitte was the only accounting firm that maintained this capability in the period immediately following the enactment of SOX. Thus, I posit that in comparison to its Big 4 competitors, Deloitte was incrementally more likely to maintain audit relations with clients operating in industries in which it was a specialist.

To illustrate this conjecture consider a market with two competitors: one having the capability to offer only auditing services and the other having to decide how to allocate resources between auditing and consulting. When offering audit services the latter company incurs an opportunity cost of not being able to offer consulting. As a result, it is careful in choosing auditing only if its comparative advantage truly lies in the provision of this service. Industry specialization enhances the likelihood that this is indeed the case. While industry specialization was an important factor in explaining the continued auditing relationships of all Big-4 firms, it was especially important in the case of Deloitte, given that this was the only firm that had to assess whether its strength in serving a given client was really in auditing rather than consulting. Applying this theory to the empirical setting of the paper, I predict that: 


\section{H1: Among Big 4 auditor switches, Deloitte was less likely to experience switches with industry specialist clients.}

\subsection{Historical Dependence of the Audit Firm to Provide Consulting Services}

Prior literature concerning auditor-provided consulting services has largely examined the effect of these services on audit fees (Simunic 1984, Palmrose 1986, Firth, 2002, Whisenant et al. 2003) and auditor independence (Frankel et al. 2002, Defond et al. 2002, Kinney et al. 2004) in the period before the mandated separation of audit and consulting services. While these papers help explain the relationship between audit and consulting services before SOX, they do not help researchers predict which clients are more likely to prefer consulting over audit services after the mandated separation. In the absence of guidance from prior research, I choose the historical procurement of consulting services as the primary predictor of this preference. I conjecture that the historical provision of consulting services should be positively associated with the decision to continue the consulting rather than the audit relationship after the mandated separation. While the presence of consulting services in one period does not guarantee its continued procurement over time, data suggests that between 2000 and 2002, half of the variation in non-audit fees classified as "IT" and "other", could be explained by the prior year's similarly classified non-audit fees. Thus, while not as persistent as audit fees, the historical procurement of consulting services may still be a good predictor of a client's demand for such services in the future. In addition, prior literature in economics and accounting highlights the importance of trust among parties in the contracting process

\footnotetext{
${ }^{7}$ Prior literature has examined the contents of non-audit fees and found that the proscribed SOX services, including consulting services, are most likely to reside in the "IT" or "other" non-audit fee category (Kinney et al, 2004). I will discuss the proxies used to capture the procurement of consulting services in the research design section of the paper.
} 
(Neu, 1991, Burchell et al., 1997). This line of research suggests that firms are likely to consider prior relationships as they select a consulting provider.

Applying this conjecture to the empirical setting of this paper, Deloitte should be the only firm to experience auditor switches due to the joint auditor/client decision to provide consulting rather than audit services, as it was the only accounting firm with the capability to provide both services after SOX. To the extent that historically high levels of consulting services predict continued procurement of these services, Deloitte and their joint service clients should be more likely to continue the consulting relationship and discontinue the audit relationship. Thus, I present the following formal hypothesis:

\section{H2: Among Big 4 auditor switches, Deloitte was more likely to experience switches with clients that historically procured high levels of consulting services.}

\subsection{Likelihood That the Client Will Procure Consulting Services in the Future}

Although the historical procurement of consulting services may be a good indicator for the joint auditor/client dependence on these services, examining this factor in isolation is likely insufficient to determine whether the client is a better candidate for consulting rather than audit services. In fact, prior literature has provided evidence that non-audit services are positively associated and endogenously determined with audit fees (Simunic, 1984; Palmrose, 1986; Whisenant et al., 2003, Antle et al., 2006). For example, company-specific events, such as acquisitions and new issues, generate demand for consulting services, and usually result in increased audit effort and fees (Firth, 2002). In addition, client characteristics, such as size and complexity, influence both audit and non-audit fees (Firth, 1997). Thus, the historical dependence on the auditor to provide 
consulting services may be an indicator that the client is a good candidate for both audit and consulting services. In order to identify clients that are better candidates for consulting, I examine factors which are likely to influence the future consulting requirements of that client. I predict that accounting firms consider the likelihood that future consulting engagements will be recurring before they decide to provide consulting rather than auditing services to their joint service clients. I propose the following four factors as important determinants of clients' future demand for consulting services: (1) high free cash flow, (2) a history of M\&A activity, (3) a history of new issues, and (4) high growth opportunities.

\section{1) Free Cash Flow}

Prior literature suggests that free cash flow (FCF) can influence non-audit fees because firms with more free cash flow have a greater ability to pay for these services. Mitra et al. (2007) provide marginal support for this association. In addition, Jensen (1986) posits that managers of firms with high levels of FCF are more likely to engage in empire building, including mergers and other "pet projects". While empire building is generally detrimental to investors, it may necessitate the involvement of outside consultants. Because FCF may enable managers to allocate resources to projects requiring consultants, accounting firms and their high-FCF clients are likely to favor the consulting over the audit relationship. On the other hand, Gul et al. (1997) provide evidence that FCF is also positively associated with audit fees. They argue that this relationship derives from managers using the free cash flow to engage in non-value

maximizing activities. These activities increase agency costs and auditors assessments of 
inherent risk. Thus, auditors are more likely to increase fees to compensate for this additional risk. Because the literature suggests that FCF is positively associated with both audit and non-audit fees, accounting firms may place increased value on both the audit and consulting relationships with high-FCF clients. In order to capture the likelihood that the consulting relationship is more valuable than the audit relationship, I assess the effect of FCF in conjunction with the historical procurement of consulting services. I posit that accounting firms and their high-FCF clients will be more likely to discontinue the audit relationship and continue the consulting relationship when auditors provided high levels of consulting services to those clients in the past.

\section{2) Merger and Acquisition Activity}

Firth $(1997,2002)$ provides evidence that a history of M\&A activity is positively associated with the purchase of non-audit services. The additional work required to guarantee the success of a merger or acquisition increases the likelihood that the firm will "seek assistance of a consultancy firm to help them at the planning stage and, more importantly, the post event stage" (Firth, 2002). Thus, future consulting engagements may result from prior-period M\&A activity. In addition, a stream of literature identifies a subset of firms that make multiple acquisitions over a given period (Fuller et al. 2002, Klasa et al. 2007). Klasa et al. find that multiple takeovers occurring in a sequence made up more than $25 \%$ of merger and acquisition activity from 1982 to 1999 . Hence, for many firms, the presence of prior M\&A activity may increase the likelihood of future M\&A activity, and thus lead to a continuing demand for consulting services. This 
argument would suggest that accounting firms and their clients would favor the consulting over audit relationship when there is a history of M\&A activity.

On the other hand, M\&A activity has also been shown to be positively associated with audit fees (Firth 2002). Auditors must learn about the new subsidiary's accounting systems and perform additional work to ensure that consolidation of the entities adheres to the accounting rules. This additional work is accompanied by increased audit fees. As a result, the effect of $M \& A$ on the preference for future audit or consulting work is ambiguous. In order to capture the likelihood that the consulting relationship is incrementally more valuable than the audit relationship, I assess the effect of M\&A activity in conjunction with the historical procurement of consulting services. I predict that accounting firms and their clients will be more likely to discontinue the audit relationship and continue the consulting relationship in the presence of M\&A activity and historically-procured auditor-provided consulting services.

\section{3) New Issues}

Firth $(1997,2002)$ also provides evidence that a history of debt and equity issues is positively associated with the purchase of non-audit services. The proceeds of new issues are often invested in new assets and business activities. Outside consultants may help identify and integrate new assets and businesses into the firm. If the proceeds from the new issue are used to fund major changes in the accounting or information systems of the firm, accounting firms are especially well suited to design and implement these new systems. Hence, post-issue activities often lead to even more consulting work becoming available to the accounting firms. 
As opposed to the prior factors, new issues of debt and equity have not been linked to increased audit fees (Whisenant et al. 2003). Thus, I unambiguously predict that accounting firms and their clients are more likely to favor the consulting rather than the audit relationship for firms that have recently issued new debt or equity. Nonetheless, the association between new issues and the decision to provide consulting rather than audit services should be more significant for firms that historically procured high-levels of consulting services from their auditor. These clients are more likely to choose their incumbent auditors for consulting services as they apply the proceeds of the new issues.

\section{4) Growth Opportunities}

The finance literature provides evidence that M\&A activity, new issues of debt and equity, and the combination of the two are associated with the underlying growth opportunities of the firm (Martin 1996, Klasa et al. 2007). Thus, the presence of growth opportunities may eventually lead to M\&A activities and new issues which in turn result in the hiring of consultants. In addition, prior literature in accounting suggests that firms with high growth opportunities are likely to purchase more consulting services because of the rapid expansion in firm activities (Firth 1997, Gul et al. 2006). This expansion may impose time and resource constraints on managers and result in the firm hiring consultants to fill the void. Hence, even in the absence of specific events such as M\&A and new issues, high levels of growth opportunities may result in accounting firms and their clients favoring the consulting over the audit relationship.

Again, prior literature also provides evidence that high growth opportunities are positively associated with both audit and non-audit services (Whisenant et al. 2003). 
Therefore, firms with high growth opportunities may be good candidates for both audit and consulting. Similar to the prior determinants of future consulting needs, I examine the interaction between growth opportunities and the historical procurement of auditorprovided consulting services. I predict that firms with high growth opportunities that historically relied on the auditor to provide consulting services will be more likely to continue the consulting rather than the audit relationship after the mandated separation of these services.

Prior research has identified at least three other factors which increase the likelihood that clients will purchase auditor-provided consulting services in a given period. These factors include: (1) the installation of new accounting and information systems, (2) CEO changes, and (3) substantial reorganizations and restructurings. I do not examine the effect of these events on the likelihood that the client will require consulting services for the following reasons. First, I do not have the data to examine the effect of new installations of accounting and information systems. Even if such data were available, an examination of this event may be redundant, because installation of accounting systems often follows new issues of debt or equity and the incorporation of a new entity (M\&A activity). In addition, high levels of growth opportunities may indicate a need for more frequent updating of the accounting and information system. In the case of CEO changes and firm reorganization, I argue that such occurrences may represent one-time events that spur the need for consulting in the current period, but do not necessarily increase the likelihood that the client will require consulting services in the future. Thus, I do not examine these factors in my empirical analysis. 
Collectively, I classify the four determinants identified above as factors that increase the likelihood that the client will require consulting services in the future. Because these factors may be associated with the desirability of providing both audit and consulting services, I examine the effect of these factors in conjunction with the historical auditor/client dependence on consulting services. The joint effect of prior auditor involvement in consulting and the client's future consulting needs should indicate that the consulting relationship is incrementally more valuable than the audit relationship to both the accounting firm and its clients. Applying this prediction to the empirical setting of this paper, I present the following formal hypothesis:

\section{H3: Among Big 4 auditor switches, Deloitte was more likely to experience switches with clients that historically-procured high levels of consulting services and had an increased likelihood of requiring consulting services in the future.}

\subsection{The Effect of Choosing Consulting on Audit Fees and Quality}

While the factors influencing the joint auditor/client choice between auditing and consulting is interesting from the perspective of researchers and practitioners, regulators are likely more concerned about the effects of this choice on audit efficiency and effectiveness. One such concern is that the audit switch mandated by SOX when choosing consulting over audit services will lead clients to select an inferior successor auditor in terms of quality and efficiency. Even though Deloitte might have been a superior audit provider in comparison to its competitors, such clients had to switch to an alternative auditor if they considered Deloitte's consulting services of higher added value than its audit services. 
In addition, joint service clients that continued the consulting relationship with Deloitte and required the services of a large globally-connected audit provider had to choose among the three remaining Big 4 accounting firms ${ }^{8}$. Non-Deloitte switchers requiring the services of a Big 4 accounting firm had a larger set of four firms from which to choose ${ }^{9}$. Government organizations, such as the GAO, have expressed concerns about the shrinking number of large public accounting firms (GAO 2003, 2008). As with other highly concentrated industries, regulators and legislators worry that such contraction may result in increased fees and reduced quality of service. If intensified competition forces accounting firms to pay closer attention to quality and efficiency, then Deloitte's successor auditors might have had reduced incentives to offer competitive rates and provide high quality services. This is especially true if the remaining two firms (other than Deloitte and the successor auditor) did not have the expertise or geographic presence to provide audit services to the client.

Based on these arguments, I expect Deloitte's joint service switchers to experience a relatively larger increase in their post-switch audit fees. This increase may stem from the loss of audit efficiency or monopoly power exercised by the successor auditors to extract additional rents from clients. In line with both arguments, I propose the following hypothesis:

\section{H4: In comparison to the joint service switchers of its Big 4 competitors, Deloitte's joint service switchers were more likely to experience a post-switch increase in audit fees.}

\footnotetext{
${ }^{8}$ Section 201 requires the cessation of providing all SOX-proscribed non-audit services at least a year before providing audit services. Thus, Deloitte switchers that continued the consulting relationship were required to wait at least two year before rehiring Deloitte as its auditor (assuming a one-period consulting relationship).

${ }^{9}$ Non-Deloitte switchers could have continued to procure audit services from their current auditor. Unlike Deloitte's independenceinduced switchers, the non-Deloitte switches were not mandated by regulators.
} 
To the extent that the subsequent auditor does not have the expertise and does not allocate sufficient audit effort to match the level of service provided by Deloitte, I expect post-switch audit quality to deteriorate. On the other hand, reputation losses and litigation resulting from audit failures may lead the subsequent auditor to exert the effort necessary to maintain Deloitte's quality of service. Therefore, it is unclear whether, postswitch, Deloitte's clients experienced audit quality deterioration in comparison to other switchers. Nevertheless, conditional on finding insignificant results for H4, I propose the following hypothesis:

H5: In comparison to the joint service switchers of its Big 4 competitors, Deloitte's joint service switchers were more likely to experience a post-switch decrease in audit quality. 


\section{EMPIRICAL RESEARCH DESIGN}

\subsection{Testing the Influence of Auditor Industry Specialization and the Historical Level of} Auditor-Provided Consulting Fees on Auditor Switch Decisions (H1 and H2)

To test the first two hypotheses, I examine the probability that Deloitte auditor switches are different from auditor switches of the other Big 4 accounting firms. I test whether Deloitte switches are less likely to involve clients in industries where the auditor is a specialist (H1), and more likely to involve clients with high levels of auditorprovided consulting services $(\mathrm{H} 2)$. Because Deloitte was the only Big 4 firm to retain its consulting division post-SOX, I investigate whether the characteristics of Deloitte switches differed from its competitors' switches in the predicted manner. I examine auditor switches from July 30, 2002 to December 31, 2004; the two and a half year period after the enactment of SOX. I employ the following logistic model based on pooled cross-sectional data for all Big 4 audit switch clients over the sample period ${ }^{10}$ :

Deloitte_Switch $_{i, t}=\alpha+\beta_{1}($ OtherandIT_Fees_2001 $i)+\beta_{2}($ Ind_Spec $i, t-1)+\beta_{3}\left(\right.$ Tenure $\left._{i, t-1}\right)$

$+\beta_{4}\left(\right.$ Disc_Accr $\left.{ }_{i, t-1}\right)+\beta_{5}\left(A A \_a c q c i t y \_d u m m y_{i}\right)+\beta_{6}\left(H i g h \_L i t i g a t i o n \_D u m m y_{i, t}\right)+$ $\beta_{7}\left(\right.$ Regulated_Dummy $\left._{i, t}\right)+\beta_{8}\left(\right.$ Disagree $\left._{i, t}\right)+\beta_{9}\left(\right.$ Resigned $\left._{i, t}\right)+\beta_{10}\left(\right.$ Merger $\left._{i, t}\right)+$ $\beta_{11}\left(\right.$ Internal_Control_Issue $\left.e_{i, t}\right)+\beta_{12}\left(\right.$ Accounting_Issue $\left._{i, t}\right)+\beta_{13}\left(\right.$ Audit_Opinion_Issue $\left._{i, t}\right)$ $+\beta_{14}\left(\right.$ Downgrade_Big4 $\left._{i, t}\right)+\beta_{15}\left(\right.$ Going_Concern $\left._{i, t}\right)+\beta_{16}\left(\right.$ Log_Size $\left._{i, t-1}\right)+\beta_{17}\left(\right.$ Liq $\left._{i, t-1}\right)+$ $\beta_{18}\left(\right.$ Leverage $\left._{i, t-1}\right)+\beta_{19}\left(\right.$ Loss $\left._{i, t-1}\right)+\sum \gamma_{\mathrm{j}}$ EEARDUM $_{j}+\sum \gamma_{\mathrm{j}} \operatorname{INDDUM}_{j}$

All variables are defined in Appendix C.

\footnotetext{
${ }^{10}$ I implement this analysis using Huber-White standard errors, which are robust to arbitrary heteroscedasticity and serial correlation.
} 
I define the dependent variable in equation (1) as a dummy variable equal to one if the predecessor auditor was Deloitte; zero if the predecessor auditor was any Big 4 firm other than Deloitte (Deloitte_Switch). I limit the control sample to auditor switches of Deloitte's direct competitors (PWC, Ernst \& Young, and KPMG), because I want to compare audit clients that are similar on as many dimensions as possible (such as size, complexity, and risk). In addition, I limit the control sample to accounting firms that were active in the consulting market before the spin-off of their consulting divisions. Non-Big 4 accounting firms were less active in consulting ${ }^{11}$, and were more likely to audit a different cross-section of firms (smaller, less complex clients) ${ }^{12}$. Thus, in order to isolate the ability to provide consulting services after SOX while limiting the fundamental differences between the switching clients, I limit the sample to Deloitte and its Big 4 competitors.

One potential drawback of this research design is the inability to capture the client composition of these accounting firms at the time of the switch. To the extent that Deloitte's full client composition was different from that of its competitors, it might have experienced a different incidence of auditor switches unrelated to its intention to continue the consulting relationship. I decided to limit the sample to audit switch clients for the following reasons. First, prior research provides evidence that there are fundamental differences between firms that remain with their auditor in a given year and firms that

\footnotetext{
${ }^{11}$ In 2001, the average ratio of non-audit fees to total fees for public companies was about $45 \%$ for the Big 5 firms (excluding AA), and only $25 \%$ for the large second tier firms (including BDO Seidman, Grant Thornton, and McGladrey \& Pullen). In addition, the majority of the second tier non-audit fees were for tax services (Barton, 2005). Thus, while Deloitte's second-tier competitors had consulting capabilities, they were not as robust as Deloitte's Big 5 competitors. Even so, including the BDO Seidman, Grant Thornton, and McGladrey \& Pullen auditor switches in the sample does not change any of the results of the paper.

${ }^{12}$ In 2001, only $2.5 \%$ of public companies listed in Audit Analytics were audited by Non-Big 5 firms. In addition, these public companies were much smaller than those audited by the Big 5 firms. The average market value of equity of the Big 5 (excluding AA) and Non-Big 5 public clients was 1,890.6 million and 117 million, respectively (Barton, 2005).
} 
switch to another auditor. While some of these differences can be controlled for in the empirical design, many factors are more difficult to capture empirically. The data disclosed in relation to an audit switch is much more comprehensive than that available in the absence of such a switch. It may include, for example, information related to the existence of disagreements with the auditor about accounting principles or accounting treatments. It can also reveal questions regarding the veracity or applicability of previous or upcoming audit opinions. Such information remains undisclosed when clients continue to procure audit services from the same auditor. By limiting the sample to switching firms and incorporating the additional information that becomes available with switches, I am less likely to obtain spurious results derived from differences between switchers and non-switchers that would be difficult to control for in an alternate empirical design. ${ }^{13}$

In addition, my objective in this study is to capture the decision by Deloitte and its clients of whether to continue the audit or the consulting relationship. I believe that variables that determine this choice are much more difficult to identify for non-switching companies. There are a number of reasons why a company may choose to remain with its auditor that are unrelated to the added value of the firm's auditing versus consulting services. For instance, while clients can discontinue the consulting relationship at any time, they are required to obtain a yearly audit opinion. Moreover, the long term relationship between clients and their auditors may create a bonding that is difficult to break, which may lead to inertia in favor of keeping the same auditor. These dynamics have very little to do with clients' conscious choice regarding the procurement of audit

\footnotetext{
${ }^{13}$ This alternate design would regress the decision to switch auditors on the interaction between Deloitte clients and the hypothesized factors that influence the decision to continue the audit or consulting relationship.
} 
versus consulting services. The advantage of my research design is that I capture a sample of firms that actively decided to switch auditors. I am able to examine whether firms were more or less likely to make this decision based on the hypothesized factors described above. Although the research design limits the sample to switching firms, I also report possible differences in the types of clients audited by Deloitte and its competitors in order to address some of the concerns that Deloitte's full composition of audit clients was fundamentally different from that of its competitors' clients (see Table 2).

In model (1), I test the statistical significance of two independent variables of interest: (1) Ind_Spec and (2) OtherandIT_Fees_2001. Ind_Spec is a dummy variable equal to one if the predecessor auditor is a national-level industry specialist; zero otherwise. Prior literature has proxied for auditor industry specialization by measuring the market share of an auditor in a given industry. Market share is captured based on the audit fees derived from clients. Following Neal and Riley (2004), the appropriate cutoff for the market share percentage that results in industry specialization is given by $(1 / \mathrm{N}) * 1.2$. By 2003, Arthur Andersen had already been forced out of business, leaving four Big $\mathrm{N}$ firms vying for market share. Hence, when $\mathrm{N}=4$, an auditor holding more than $30 \%$ market share is considered a specialist. While most papers have captured industry specialization on a national-level, recent literature suggests that specialization also influences audit quality and audit fees at the city-level (Ferguson et al., 2003, Francis et al., 2005). Thus, as a robustness test, I also examine the influence of joint national and city level specialization. The results are consistent between national and joint national- 
city levels of industry specialization. Based on H1, I predict that the coefficient on Ind_Spec will be negative and significant, suggesting that Deloitte was less likely to switch away from (or be dropped by) its clients in industries where it was considered a specialist.

The other independent construct that I operationalize in this model is the historical reliance on the auditor to provide consultancy services. The main challenge in empirically capturing this construct is to identify the categories of non-audit services that were likely to contain consulting services supplied by the external auditor. Based on the limited amount of publicly available data, I chose to capture this construct by taking the sum of non-audit fees classified as Other or IT in the year 2001 (OtherandIT_Fees_2001).

The U.S. Securities and Exchange Commission (SEC) issued financial reporting release (FFR) No. 56 requiring public companies to disclose the total fees, audit fees, financial information system design and implementation (IT) fees ${ }^{14}$, and other non-audit fees paid to the external auditor in their proxy statements filed on or after February 5, 2001 (SEC, 2000). Although firms were not required to break out the tax and auditrelated portions of non-audit fees until the enactment of FFR No. 68 in 2003 (SEC, 2003), many firms voluntarily provided more details on these types of non-audit services (by separately reporting tax, benefit, and audit-related fees in 2001 and 2002.) In this paper, I am interested in capturing the historical dependence on consulting services

\footnotetext{
${ }^{14}$ Financial information system design and implementation services include (i) operating or supervising the operation of an information system or managing a local area network; and (ii) designing or implementing a hardware or software system that aggregates source data underlying the financial statements or generates information that is significant to the Company's financial statements taken as a whole.
} 
before the provisions of Section 201 of SOX were implemented ${ }^{15}$. Therefore, I focus on the available public disclosures of non-audit fees reported in 2001 and 2002. The consulting services I am attempting to capture during this time period were most likely included in the "financial information system design and implementation (IT) fee" bucket and buried in the "other non-audit fee" bucket. The independent variable I selected sums the non-audit fees classified as IT and other (OtherandIT_Fees), and from the two years available, I use the 2001 data (OtherandIT_Fees_01).

In 2000, both Ernst \& Young and KPMG agreed to spin off and sell their consulting divisions to Cap Gemini and Bearing Point, respectively. They also signed non-competition agreements with these acquirers, giving up the right to provide management and strategy advisory services as well as IT design and implementation services. Both merger deals were not fully completed until 2001, so E\&Y and KPMG continued to provide small amounts of consulting services to their audit clients in that year. In particular, IT consulting services proscribed in the non-competition agreements continued to be supplied to a limited number of clients ${ }^{16}$. In addition, the non-compete agreements did not disallow the provision of certain types of consulting services to audit clients, including transaction advisory services and internal audit outsourcing. These services were later proscribed in Section 201 of SOX.

\footnotetext{
${ }^{15}$ Section 201 of SOX took effect 180 days after the date of commencement of the operation of the Public Company Accounting Oversight Board (PCAOB) established under section 101 of SOX. Given that the Washington, D.C. PCAOB office officially opened on January 6, 2003, Section 201 did not take effect until July 4, 2003. Thus, even though SOX was enacted in the middle of 2002, accounting firms could continue to provide audit and proscribed non-audit services for all audits relating to 2002 .

${ }^{16}$ According to the data provided in Audit Analytics, in $2001 \mathrm{E} \& \mathrm{Y}$ and KPMG provided IT related services to 10 and 27 public audit clients, respectively. Comparatively, PWC and Deloitte provided IT services to 93 and 64 public audit clients. Based on firms that voluntarily provided non-audit service data in 2000, KPMG, E\&Y, and Deloitte provided similar amounts of IT services to a similar number of clients (PWC provided about two times as much as the other three firms). By 2002, all IT services were discontinued for both EY and KPMG.
} 
While the composition and volume of consulting services offered by Deloitte in 2001 were probably different from those offered by its competitors (particularly E\&Y and KPMG), I believe that using the 2001 data does not hinder my analysis, given the objectives of this study. Even if the composition and volume of service were similar for all firms in 2001, Deloitte was the only firm that could offer the full array of consulting services post-SOX. Based on their non-compete agreements, PWC, E\&Y, and KPMG could have provided certain types of consulting services, such as transaction advisory services and internal audit outsourcing, but unlike Deloitte, their clients could not procure the more high-value management advisory services and IT design and implementation services. Thus, while the clients of the other Big 4 firms could have severed ties with their auditor in order to procure a more limited array of consulting services, I posit that Deloitte clients were more likely to value the comprehensive mix of consulting services offered. It is exactly this incremental value that I am trying to identify in this model. Ideally, it would have been preferable if I could use data of non-audit services in a year when the composition and volume were likely to be similar across all Big-4 firms (1999 or 2000, for instance). Unfortunately, there is limited publicly available data regarding this variable prior to $2001^{17}$. Given the possible differences in the composition of nonaudit services provided by KPMG and E\&Y in 2001, as a robustness test, I limit the

\footnotetext{
${ }^{17}$ A limited number of firms voluntarily disclosed the non-audit fees paid to their auditor in 2000 , but the decision to disclose was likely endogenous to the characteristics of the client. For example, firms with relatively low-levels of non-audit fees were more likely to voluntarily disclose this information, because there was a lower risk that investors would perceive this incidental expenditure as an impairment of auditor independence. Thus, measuring this variable in 2000 rather than 2001 would possibly result in a biased sample of firms with relatively low-levels of auditor-provided consulting services. In addition, using the limited data available from the earlier year would greatly reduce the sample size. Therefore, I decided to capture OtherandIT_fees using the year 2001 mandatory disclosures rather than the year 2000 voluntary disclosures.
} 
control sample to switching clients of PWC only ${ }^{18}$. See the sensitivity analysis section for a discussion of the similarities and differences in results.

The primary measure I employ in model (1) is the log of other and IT non-audit fees in 2001 (Log_OtherandIT_Fees_2001). I argue that the value of consulting services to auditors and their clients is best captured by the actual size of the consulting fees (logged for non-linearity concerns). To the extent that the theoretical construct is best captured by clients relative dependence on the consulting service compared to all services provided (Frankel et al. 2002), I also examine the ratio of Other and IT fees to total fees (Ratio_OtherandIT_Fees_2001). Finally, I examine whether the presence of these fees (Dummy_OtherandIT_Fees_2001) influences the decision to procure consulting services in the future.

The remaining variables included in the model control for possible differences in the types of auditor switches between Deloitte and the other three Big 4 firms. I describe the rationale for including these variables in Appendix D.

\subsection{Testing the Influence of the Historical Level of Auditor-Provided Consulting Fees}

Interacted with the Likelihood the Client Will Require Consulting Services in the Future on Auditor Switch Decisions (H3)

In support of H3, I examine the probability that Deloitte auditor switches involve clients that are more likely to historically procure high levels of consulting services and require consulting services in the future. To test this hypothesis, I augment model (1) by incorporating the four factors likely to influence whether the client is a good candidate

\footnotetext{
${ }^{18}$ PWC spun off and sold its consulting division to IBM in 2002. At that time, PWC signed a non-competition agreement restricting its ability to provide MAS and IT design and implementation services. However, in 2001 it still had an active consulting division.
} 
for consulting services and interact these factors with my proxy for the historical reliance on consulting services (OtherandIT_Fees). The four factors identified are likely correlated with one another. Thus, I incorporate them individually in four different regressions rather than including them all in one model. The four factors I identify are: (1) high free cash flow, (2) a history of M\&A activity, (3) a history of new issues, and (4) high growth opportunities.

Consistent with prior research (Artiach et al., 2010), free cash flow $(F C F)$ is defined as Net Cash Flow from Operating Activities minus Cash Dividends minus Capital Expenditures. To the extent that the prior year level of free cash flow is idiosyncratic to that particular year, I average FCF over the previous three years $\left(A v g 3 \_F C F\right)^{19}$. My primary measure for M\&A activity is the presence of a merger or acquisition in the current or prior year ${ }^{20}$. If M\&A activity occurred during this period then $M \& A$ is equal to 1 ; else 0 . I capture new issues with a dummy variable equal to 1 if the firm has equity or long-term debt issues above a certain threshold ${ }^{21}$ in the current or prior year; zero otherwise (New_Issue). Prior research generally captures the construct of growth opportunities with either the market to book ratio (MTB) or the Tobins $\mathrm{Q}$ ratio (Tobins $Q$ ). MTB is defined as the market value of equity divided by the book value of equity. TobinsQ is defined as the market value of assets divided by the current replacement cost of those assets. I report the results using the MTB ratio and examine

\footnotetext{
${ }^{19}$ The results are invariant to alternative constructions of the free cash flow variable including current year and one-year lagged FCF. ${ }^{20}$ This variable is not influenced by the Merger variable included as a control variable. $M \& A$ identifies prior year M\&A activity where the firm was an acquirer and the combined company remained with the same auditor. Merger is only equal to one when the firm is a target and is required to switch to the acquirer's auditor.

${ }^{21}$ To minimize the effect of stock transactions with employees confounding the New_Issue variable, I require new equity to be greater than $\$ 10$ million (Whisenant et al 2003). I also require long-term debt issuances to exceed $\$ 1$ million in a given year to minimize the likelihood that the issuance is immaterial. My findings are robust to alternative thresholds of debt issuance size (\$0 and $\$ 10$ million).
} 
whether the results are robust to the alternate measure, TobinsQ. Similar to FCF, I average the growth opportunity variables over the prior three years (Avg3_MTB and Avg3_TobinsQ).

\subsection{Testing the Efficiency Losses resulting from Deloitte's Independence-Induced Auditor} Switches (H4)

To test H4, I examine whether audit fees increased by a greater amount for joint service clients switching away from Deloitte. The independence requirements inherent in SOX may have induced some of Deloitte's joint service clients to switch to less suitable and efficient auditors. In addition, the increased concentration of the audit market that such clients faced may have resulted in the subsequent auditors offering less competitive rates to former Deloitte clients. In either case, Deloitte's joint service clients are expected to experience larger post-switch audit fee increases as compared to the increases experienced by concurrent non-Deloitte joint service switchers.

I apply the following OLS regression based on pooled cross-sectional data for all Big 4 auditor switches from July 30, 2002 to December 31, 2004 to test this prediction:

$$
\begin{aligned}
& \text { Chg_Log_Audit_Fees } s_{i, 2004-2002}=\alpha+\beta_{1}(\text { OtherandIT_Fees_2001 })+\beta_{2}(\text { Deloitte_Switch } i, t) \\
& +\beta_{3}\left(\text { OtherandIT_Fees_2001 } * \text { Deloitte_Switch }{ }_{i, t}\right)+\beta_{4}\left(\text { Chg_Log_Size } e_{i, 2004-2002}\right)+ \\
& \beta_{5}\left(C h g \_I n v R e c_{i, 2004-2002}\right)+\beta_{6}\left(C h g \_R O A_{i, 2004-2002}\right)+\beta_{7}\left(\text { Chg_Leverage } e_{i, 2004-2002}\right)+ \\
& ß_{8}\left(C h g \_B i g 4_{i, 2004-2002}\right)+\beta_{9}\left(C h g \_S e g m e n t s_{i, 2004-2002}\right)+\beta_{10}\left(I C W_{i, 2002 \text { to } 2004}\right)+ \\
& ß_{11}\left(\text { LossYear }_{i, 2002 \text { to 2004 }}\right)+\sum \gamma_{\mathrm{j}} \text { YEARDUM }_{j}+\sum \gamma_{\mathrm{j}} I N D D U M_{j}
\end{aligned}
$$


All variables are defined in Appendix C. The main variable of interest in model (2a) is the interaction between Deloitte_Switch and OtherandIT_Fees_2001. The coefficient of this interaction variable $\left(\Omega_{3}\right)$ is expected to be positive and significant. To the extent that Deloitte's independence-induced joint service switches were followed by a less efficient or competitively priced audit, this should be reflected in higher audit fee increases. The coefficient $\beta_{3}$ captures the differential fee increase for this group of Deloitte switches. The remaining variables in model (2a) control for firm specific factors that have been shown to influence audit fees (See Simunic, 1980, Palmrose, 1986, Whisenant, 2003, Causholli, 2009). I measure these audit fee determinants in terms of changes for consistency with the way I measure the dependent variable.

I define the dependent variable in equation (2a) as the change in the log of audit fees between 2002 and 2004. I choose to examine audit fee changes between 2002 and 2004 regardless of whether the auditor change occurred in 2002, 2003 or 2004. Audit fees for "accelerated" public accounting firms increased by a greater amount between 2003 and 2004 as compared to the increase in the prior year (2002 to 2003). In 2004, Section 404 of SOX (SOX 404) was implemented requiring auditors to attest to and report on the effectiveness of the client's internal control structure and procedures for financial reporting. Prior studies provide evidence that, on average, the additional work requirements associated with SOX 404 more than doubled audit fees between 2003 and 2004 (Krishnan et al. 2008). To standardize the effect of auditor switches on audit fee increases regardless of whether the switch was made in 2002, 2003 or 2004, I hold constant the effect of SOX 404 by analyzing fee increases over a comparable time period 
for all firms in the sample. This approach reduces the likelihood of obtaining spurious results if Deloitte switches were more prevalent in one of the three sample years.

Nonetheless, this approach of capturing audit fee changes over a two year window may unnecessarily elongate the measurement period. If other events or firm changes that influence audit fees occur during the non-switch year, then this approach induces noise in the analysis. In addition, including year fixed effects in the model partially controls for the impact of SOX 404. Because of this concern with the two-year measurement window, I also examine audit fee changes over a shorter window. This alternate approach captures one-year lagged audit fee changes in the following model:

$$
\begin{aligned}
& \text { Chg_Log_Audit_Fees } i_{i, t-(t-1)}=\alpha+\beta_{1}(\text { OtherandIT_Fees_2001 } i)+\beta_{2}\left(\text { Deloitte_Switch }_{i, t}\right)+ \\
& \beta_{3}\left(\text { OtherandIT_Fees_2001 } * \text { Deloitte_Switch }{ }_{i, t}\right)+\beta_{4}\left(\text { Chg_Size } e_{i, t-(t-1)}\right)+ \\
& \beta_{5}\left(\text { Chg_InvRec } c_{i, t-(t-1)}\right)+\beta_{6}\left(\text { Chg_ROA }_{i, t-(t-1)}\right)+\beta_{7}\left(\text { Chg_Leverage }{ }_{i, t-(t-1)}\right)+\beta_{8}\left(\text { Chg_Big4 }_{i,}\right. \\
& t-(t-1))+\beta_{9}\left(\text { Chg_Segments }_{i, t-(t-1)}\right)+\beta_{10}\left(\text { ICW }_{i, t-1 \text { to } t}\right)+\beta_{11}\left(\text { LossYear }_{i, t-1 \text { to } t}\right)+ \\
& \sum \gamma_{\mathrm{j}} Y E A R D U M_{j}+\sum \gamma_{\mathrm{j}} I N D D U M_{j}
\end{aligned}
$$

3.4 Testing the Loss of Audit Quality resulting from Deloitte's Independence-Induced Auditor Switches (H5)

The SOX-induced auditor switches resulting from the choice to continue the consulting rather than the audit relationship may also lead to a decline in audit quality. A joint service client choosing consulting may have stayed with Deloitte as its audit provider had the provisions of SOX not forced an auditor switch. Other market driven auditor switches normally result from clients identifying a more suitable audit provider. Joint service clients selecting consulting may therefore have been forced to move to a 
successor auditor who did not have the expertise to maintain the quality of audit service previously offered by Deloitte. Two proxies that have historically been used to capture changes in audit quality should reflect this possibility: (1) post-switch increases in discretionary accruals, and (2) increased probability of post-switch restatements ${ }^{22}$.

I first test for changes in the audit quality of Deloitte's joint service switchers by analyzing the change in discretionary accruals following the auditor switch. I employ the same sample and research design as models (2a) and (2b), but replace the dependent variable (Chg_Log_Audit_Fees) with changes in discretionary accruals (Chg_Disc_Accr). I measure discretionary accruals using a cross-sectional variation of the Jones (1991) accruals estimation model modified by Dechow, Sloan, and Sweeney, $(1995)^{23}$. In addition, I replace the control variables with firm specific variables shown to vary with discretionary accruals $^{24}$ (see Geiger et al. 2006). I predict that the coefficient on the interaction between Deloitte_Switch and OtherandIT_Fees_2001 is positive and

\footnotetext{
${ }^{22}$ Alternatively, if Deloitte's independence was impaired due to the joint provision of audit and consulting services, one would predict that a switch would improve audit quality. Prior literature posits that an economic bond may be formed when an accounting firm derives high audit and non-audit service revenues from the same client (Frankel et al., 2002). Even though there is limited empirical evidence to support this conjecture (Ashbaugh et al., 2003, Kinney et al., 2004), I control for this possibility as follows. In the change in discretionary accrual model, I include the pre-switch level of discretionary accruals as a control variable. Thus, the change in discretionary accruals for Deloitte's joint service switchers is less likely to be influenced by the pre-switch level of discretionary accruals. In the post-switch restatement model, I only categorize the dependent variable as one if the misstatement period began after the switch to the subsequent auditor. If the restatement period began prior to the switch, then the dependent variable is classified as zero. Thus, Deloitte's pre-switch audit quality does not influence the categorization of this dependent variable.

${ }^{23}$ Estimation of discretionary accruals is performed as following. First, nondiscretionary accruals are estimated using the crosssectional version of the Jones (1991) model. This model estimates nondiscretionary accruals as a function of the level of PPE and changes in revenue minus changes in AR (Dechow et al (1995):

$$
\frac{T A c c_{i, t}}{T A_{i, t-1}}=\alpha_{1} \frac{1}{T A_{i, t-1}}+\beta_{1} \frac{\left(\Delta R e v_{i, t}-\Delta A R_{i, t}\right)}{T A_{i, t-1}}+\beta_{2} \frac{P P E_{i, t}}{T A_{i, t-1}}+\varepsilon_{i, t}
$$
}

where $T A c c_{i, t}$ is total accruals for firm $i$ in year $t, T A$ is total assets, $\Delta R e v$ is the change in net revenue, $\triangle A R$ is change in net accounts receivable, and $P P E$ is property, plant, and equipment. Total Accruals are calculated as the difference between net income before extraordinary item and discontinued operations and cash flows from operations. Consistent with prior research, this model is estimated separately for each combination of two-digit SIC codes, calendar years, and decile ranking of lagged return on assets (ROA). The error term in the model (the difference between total accruals and nondiscretionary accruals) represents the unexplained or discretionary component of accruals.

${ }^{24}$ These control variables include $\triangle M V E=$ change in the log of the market value of equity; $\triangle B M=$ change in the book-to-market equity ratio; $\triangle D I S T R E S S=$ change in the financial distress measure (calculated from Zmijewski 1984); $\triangle C F F O=$ change in the cash flow from operations divided by total assets; $\triangle G R O W T H=$ change in the sales growth rate; FINANCE $=1$ if number of o/s shares increased by at least 10 percent or long-term debt increased by at least 20 percent during the year; $A C Q=1$ if the company engaged in an acquisition; $\triangle R O A=$ change in the return on assets from the prior year; and Disc_Accr $=$ pre-switch level of discretionary accruals. 
significant if Deloitte's joint service switchers experienced a post-switch increase in discretionary accruals.

I then test whether Deloitte's joint service switchers were more likely to experience accounting restatements following the switch to the subsequent auditor. Again, I employ the same design as (2), but using a logistic model, I replace the dependent variable with a dummy variable equal to 1 if the firm restated its financial statements during the period beginning in the year of the audit switch and ending two years subsequent to the switch year, 0 otherwise (Post_Switch_Restate). I also replace the control variables with firm specific factors influencing the probability of accounting restatements (See Larcker et al. 2007). I predict that the coefficient on the interaction between Deloitte_Switch and OtherandIT_Fees_2001 is positive and significant. 


\section{SAMPLE SELECTION}

Table 1 outlines my sample selection criteria. I began with all U.S.-incorporated firm-year observations in the intersection of Compustat and Audit Analytics from July $30^{\text {th }}, 2002$ through the end of 2004 (25,279 firm-year observations). The decision between auditing and consulting likely began immediately after the enactment of SOX. Although the proscriptions of Section 201 did not take effect until July 4, 2003, anecdotal evidence suggests that some firms made the audit vs. consulting decision in the run up to this date ${ }^{25}$. Thus my sample period begins right after the enactment of SOX. I posit that by 2004 , accounting firms and their clients adjusted to the independence requirements of Section 201. Thus, my sample period ends in 2004. Following prior literature, I removed firms in the financial services industry (SIC codes 6000-6999) resulting in 19,009 firm-year observations. Since my sample is limited to audit switch years, I eliminated all observations where a switch did not occur resulting in 1,586 firm-year observations. The sample consists of auditor switches where the predecessor auditor was a Big 4 auditor (PWC, E\&Y, Deloitte, or KPMG). Eliminating observations where the switch involved a Non-Big 4 predecessor auditor yielded 815 firm-year observations. This elimination increases the likelihood that the composition of the control group switchers (Non-Deloitte clients) is similar to the treatment group switchers (Deloitte clients). Although the sample consists of 2002 through 2004 firm year observations, my proxy for the historical dependence on auditor-provided consulting services uses nonaudit fee data from 2001. Therefore, I eliminated observations with missing 2001 Audit

\footnotetext{
${ }^{25}$ For example, Clorox and AutoNation, decided in 2002 to discontinue the audit relationship with Deloitte in order to retain consulting relationship (See Appendix B). Conversely, General Motors decided in conjunction with Deloitte to continue the audit rather than the consulting service in 2002 (Johnson, 2003).
} 
Analytics data resulting in 655 firm-year observations. The hypothesized influence of the historical procurement of auditor-provided consulting services on the decision to provide consulting rather than audit services is likely dependent on whether Deloitte actually provided this service over the measurement period. Thus, I also eliminated firms that did not retain the same auditor between 2001 and the year of the switch, resulting in 459 firm-year observations. Finally, I delete firm-years with missing data to compute each of my regression variables. This elimination results in a final sample of 421 firm-year observations. $^{26}$ Of these 421 auditor switches, Deloitte was the predecessor auditor for 90 switches.

${ }^{26}$ Procedures used to compute each variable can be found in Appendix C. 


\section{EMPIRICAL RESULTS}

\subsection{Descriptive Statistics - Model (1)}

Table 2 presents descriptive statistics supporting model (1) in three panels. Panel A contains summary statistics of the independent variables of interest for the full sample of Big 4 audit clients (including both switchers and non-switchers). Panel B includes statistics of the independent variables of interest for the final sample of auditor switchers, and Panel $\mathrm{C}$ includes statistics of the control variables for this final sample.

While my paper investigates differences between Deloitte and non-Deloitte switchers, the underlying client composition may influence the types of clients more likely to experience an auditor switch. Thus, in panel A, I analyze the complete sample of audit clients. The variable I employ to capture the historical dependence on auditorprovided consultancy services combines Other and IT non-audit fees in the year 2001. Based on the univariate results, OtherandIT_fees (unscaled, logged, dummy, and ratio versions) is not significantly different between Deloitte and non-Deloitte Big 4 sample clients in 2001. Auditor industry specialization (Ind_Spec) and the four proxies capturing future consulting requirements $\left(A v g 3 \_F C F, M \& A, N e w \_I s s u e\right.$, and $\left.A v g 3 \_M T B\right)$ are all based on lagged versions of these variables. Univariate results suggest that there are significant differences between Deloitte and non-Deloitte clients for four of the five variables. Deloitte audited fewer clients in industries where it was an industry specialist. In addition, Deloitte's clients had lower market to book ratios, and were more likely to issue new debt or equity. The difference in free cash flow between Deloitte and nonDeloitte is ambiguous given the negative difference in means and the positive difference 
in medians for the Avg3_FCF variable. These differences in the full composition of clients may influence the type of auditor switches experienced by Deloitte vs. its competitors. Thus, as a robustness test, I control for these differences in client composition by scaling the independent variables by their pre-switch average across the entire population of clients for each auditor. I will discuss these adjustments and alternate results in more detail in section 6.

Examining differences between Panel A and B reveals that, in comparison to the full sample of clients, auditor switchers had lower free cash flow and market to book ratios, and were less likely to engage in M\&A activity and issue new debt or equity. Prior research provides evidence that auditors are more likely to resign from audit engagements with poorly performing clients (Johnson et al. 1990). Thus, these differences are reasonable and expected.

The univariate results in Panel B provide limited support for Hypotheses 1 and 2. H1 predicts that Deloitte was less likely to experience auditor switches with industry specialist clients (Ind_Spec). Summary statistics for Ind_Spec indicate a negative and marginally significant difference between Deloitte and Non-Deloitte auditor switchers. $\mathrm{H} 2$ predicts that Deloitte was more likely to experience auditor switches with clients procuring high levels of consulting services (OtherandIT_fees_01). Summary statistics for Log_OtherandIT_fees_O1 and Dummy_OtherandIT_fees_O1 reveal a positive and marginally significant difference between Deloitte and Non-Deloitte auditor switchers. Although, the univariate results provide marginal support for the hypotheses, a 
multivariate analysis that controls for other variables influencing the auditor switch decision provides more meaningful results.

Panel C reveals that, in comparison to non-Deloitte switchers, Deloitte switchers were less likely to experience a loss in the current or prior year (LossYear), and were less likely to operate in high litigation industries (High_Litigation_Dummy). The other control variables indicate no difference between Deloitte and non-Deloitte switches.

Table 3 reports Pearson and Spearman correlation matrices. The positive and significant relationship between $F C F, M T B$, and New_Issue and OtherandIT_fees_O1 is expected given my prediction that high free cash flow, high growth opportunity, and debt/equity issuing firms are more likely to procure auditor-provided consulting services. The negative and significant relationship between $M \& A$ and Dummy_OtherandIT_fees_O1 is surprising based on my prediction that clients with a history or M\&A activity are more likely to procure auditor-provided consulting services. A full correlation table (untabulated) including the main variables of interest and the control variables listed in Table 2 - Panel C reveals a number of significant correlations. However, they are not sufficiently large to affect the study's conclusions. All variance inflation factors (untabulated) are less than 2 and well below the threshold of 10, beyond which multicollinearity may become a problem (Kennedy, 1992).

5.2 Multivariate Analyses - Model (1) - Factors influencing the choice between auditing and consulting

Table 4 reports the results of multivariate logistic model (1), which regresses the probability of a Deloitte switch (Deloitte_Switch) on the proxy for historical reliance on 
auditor-provided consulting services (OtherandIT_Fees_O1), auditor industry specialization (Ind_Spec) and the control variables.

The results indicate a negative association between Deloitte_Switch and Ind_Spec ( $p$-value $<0.05)$. This result implies that Deloitte was relatively less likely to experience audit switches with clients for which it was the industry specialist auditor. Thus, it supports the contention that Deloitte was more likely to fight for the continued audit business of these high value audit clients. This finding is consistent with H1. The results of Table 4 also reveal a positive association between Deloitte_Switch and Log_OtherandIT_Fees_01 ( $p$-value < 0.10) as well as between Deloitte_Switch and Dummy_OtherorIT_Fees_O1 ( $p$-value $<0.10)$. The positive association between Deloitte_Switch and Ratio_OtherandIT_Fees_O1 is statistically insignificant. These results suggest that Deloitte was relatively more likely to experience audit switches with clients that procured auditor-provided consulting services (Dummy_OtherorIT_Fees_O1), and for clients that procured higher levels of these consulting services (Log_OtherandIT_Fees_01). These associations provide marginal support for H2. Hypothesis 3 proposes that auditors will choose the consulting over the audit relationship not only when they historically provided these services (H2), but also when the clients are more likely to require consulting services in the future. To test this proposition, I replicate the analysis in Table 4 after including two additional variables. The first variable, Consult_Likelihood, represents the four proxies capturing the likelihood that the client will require consulting services in the future. The four proxies for Consult_Likelihood include: Avg3_FCF, M\&A,New_Issue, and Avg3_MTB. The 
second variable captures the interaction effect between OtherandIT_Fees_O1 and Consult_Likelihood. The main variable of interest in this model is this interaction variable.

Table 5 reports the results of model (1) augmented to include Consult_Likelihood, OtherandIT_Fees_O1 and OtherorIT_Fees_O1*Consult_Likelihood. I only tabulate the coefficients on these three variables as Ind_Spec and the other control variables are not affected by this additional interaction.

Panel A reports the results when $A v g 3 \_F C F$ is used to capture Consult_Likelihood. I posit that firms with high cash flow have more of an ability to pay for consulting services. In addition, high free cash flow is likely to result in other firm investments, such as mergers and new information systems. These investments are often accompanied by the use of a consultant. On the other hand, the increased risk associated with the agency costs of free cash flow often results in higher audit fees. Thus, high FCF firms may also be more desirable audit clients. While high levels of FCF may be a positive attribute for both audit and consulting providers, the relative value of these services is likely dependent on the historical procurement of consulting services. I predict that high FCF firms who historically procured high levels of consulting services from their auditor (OtherandIT_Fees_O1*Avg3_FCF) are more likely to favor the consulting relationship after SOX. Conversely, high FCF firms with low levels of historically procured consulting services $\left(A v g 3 \_F C F\right)$ are more likely to favor the audit relationship. The results of Table 5 - Panel A reveal a negative association between Deloitte_Switch and Avg3_FCF for firms with low Log_OtherandIT_fees_01 ( $p$-value < 
0.01) and Dummy_OtherorIT_fees_01(p-value <0.01). Panel A also reveals a positive association between Deloitte_Switch and FCF for firms with high Log_OtherandIT_fees_01 ( $p$-value $<0.01)$ and Dummy_OtherorIT_fees_O1 $(p$-value < 0.01). Thus, Deloitte and its high FCF clients were less likely to discontinue the audit in the presence of low levels of historically procured consulting services, and were more likely to discontinue the audit (and presumably retain the consulting business) in the presence of high levels of historically procured consulting services. These findings are consistent with H3.

Panel B reports the results when $M \& A$ is used to capture Consult_Likelihood. I posit that firms with a history of M\&A activity are more likely to require consulting services to effectively synergize the new entity. On the other hand, the increased audit effort resulting from M\&A often increases audit fees. As with the prior proxy of Consult_Likelihood, I predict that Deloitte and its M\&A clients who historically procured high levels of auditor-provided consulting services (OtherorIT_Fees_O1*M\&A) are more likely to favor the consulting relationship after SOX. Conversely, Deloitte and its M\&A clients with low levels of historically procured consulting services $(M \& A)$ are more likely to favor the audit relationship. The results of Table 5 - Panel B reveal a negative association between Deloitte_Switch and $M \& A$ for firms with low Log_OtherandIT_fees_01 ( $p$-value $<0.05)$, Ratio_OtherandIT_fees_01 $(p$-value $<0.01)$ and Dummy_OtherorIT_fees_O1 $(p$-value $<0.01)$. Panel B also reveals a positive association between Deloitte_Switch and $M \& A$ for firms with high Log_OtherandIT_fees_01 ( $p$-value $<0.05)$, Ratio_OtherandIT_fees_01 $(p$-value $<0.01)$ 
and Dummy_OtherorIT_fees_01(p-value < 0.01). Thus, Deloitte and its M\&A engaging clients were less likely to discontinue the audit in the presence of low levels of historically procured consulting services, and were more likely to discontinue the audit (and presumably retain the consulting business) in the presence of high levels of historically procured consulting services. These findings are consistent with H3.

Panel C reports the results when New_Issue is used to capture Consult_Likelihood. Firms with a history of debt or equity issues are more likely to require consulting services to apply the proceeds of these issues. Prior literature does not provide any evidence that new issues influence audit fees. Thus, I only examine the influence of the interaction between OtherandIT_Fees_O1*New_Issues. The results of Table 5 - Panel C reveal a positive association between Deloitte_Switch and New_Issue for firms with high Dummy_OtherorIT_fees_O1(p-value < 0.10). Thus, Deloitte and its debt/equity issuing clients were more likely to discontinue the audit (and presumably retain the consulting business) in the presence of high levels of historically procured consulting services. Given the marginal significance (one tailed test $p$-value $<0.10$ ) of

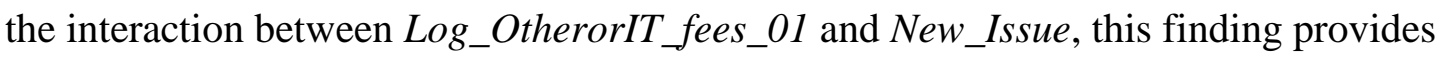
limited support for $\mathrm{H} 3$.

Panels D report the results when $A v g 3 \_M T B$ is used to capture Consult_Likelihood. Firms with high growth opportunities are more likely to require consulting services as the opportunities turn into new issues of debt and equity, R\&D spending, firm expansion and restructuring, M\&A activity, etc. Then again, high growth opportunities are positively associated with audit fees (Whisenant et al. 2003). Thus, I 
predict that Deloitte and its high growth opportunity clients who historically procured high levels of auditor-provided consulting services (OtherorIT_Fees_O1*Avg3_MTB) are more likely to favor the consulting relationship after SOX. Conversely, Deloitte and its high growth opportunity clients with low levels of historically procured consulting services $\left(A v g 3 \_M T B\right)$ are more likely to favor the audit relationship. The results of Table 5 - Panel D reveal a negative association between Deloitte_Switch and Avg3_MTB for firms with low Ratio_OtherandIT_fees_01 ( $p$-value $<0.01)$. Panel D also reveals a positive association between Deloitte_Switch and Avg3_MTB for firms with high Ratio_OtherandIT_fees_01 ( $p$-value < 0.05). Thus, Deloitte and its high growth opportunity clients were less likely to discontinue the audit when the proportion of consulting to total fees paid to the auditor was relatively low, and were more likely to discontinue the audit (and presumably retain the consulting business) when the proportion of consulting to total fees paid to the auditor was relatively high.

Given the positive, but insignificant results for the $L o g \_O t h e r o r I T \_f e e s \_01^{*} A v g 3 \_M T B$ and Dummy_OtherorIT_fees_O1*Avg3_MTB coefficients, these findings provide marginal support for $\mathrm{H} 3$.

\subsection{Multivariate Analyses - Model (2) - Loss of Audit Efficiency}

Hypothesis 4 predicts that Deloitte's joint service switchers will be more likely to experience audit efficiency losses as proxied by post-switch increases in audit fees. I test this prediction in model (2). Table 6 presents descriptive statistics supporting model (2) in two panels. Panel A contains summary statistics in support of model (2a) and Panel B contains summary statistics in support of model (2b). 
The statistics in both models reveal that audit fees changes following auditor switches (Chg_Log_Audit_Fees) were not statistically different between Deloitte and non-Deloitte switchers. Consistent with Table 2, summary statistics for Log_OtherandIT_fees_O1 and Dummy_OtherandIT_fees_O1 reveal a positive and marginally significant difference between Deloitte and Non-Deloitte auditor switchers. Other than LossYear, none of the other control variables exhibited a statistical difference between the two groups of switchers.

To test the proposition that Deloitte's joint service switchers were more likely to experience post-switch decreases in audit efficiency, I investigate the effect of the interaction between Deloitte Switch and OtherandIT_Fees_O1 on Chg_Log_Audit_Fees. Table 7 examines this effect while controlling for other firm changes that are likely to influence the change in audit fees.

Panel A indicates a positive and statistically significant association between Chg_Log_Audit_Fees and the interaction between Deloitte_Switch and Log_OtherandIT_Fees_O1 ( $p$-value $<0.10)$. The economic magnitude of the fee increase differential is $3.35 \%{ }^{27}$ when Log_OtherandIT_Fees_Olis the main independent variable of interest. In other words, the two year change in audit fees is 3.35\% larger for Deloitte joint service switchers compared to non-Deloitte joint service switchers. The positive and statistically significant association persists when Log_OtherandIT_Fees_O1 is replaced with Dummy_OtherandIT_Fees_01 ( $p$-value < 0.10).

\footnotetext{
${ }^{27}$ Economic significance of fee differential (Table 7 - Panel A - Column 1): $\exp \left(\beta 2+\beta 3\left(\right.\right.$ Median $\left.(\text { Deloitte }(\text { Log_OtherandIT_Fees_01 }))_{3}\right)=\exp (-0.558+0.054(10.943))=1.0335$
} 
The findings in Table 7 Panel B are similar to those in Panel A. Thus, the results are consistent regardless of whether Chg_Log_Audit_Fees and the related control variables are measured over the 2002 to 2004 measurement window (Panel A) or over one year lags (Panel B). Based on the one year lag construction, the economic magnitude of the fee increase differential is $4.64 \%^{28}$ when Log_OtherandIT_Fees_Olis the main independent variable of interest. In other words, the one year change in audit fees is 4.64\% larger for Deloitte joint service switchers compared to non-Deloitte joint service switchers.

The results in Table 7 indicate that in comparison to the fee increases experienced by Non-Deloitte joint service switchers, post-switch audit fees increases were larger for Deloitte's joint service switchers. This finding is consistent with Hypothesis 4. These fee increases may be a result of the subsequent auditor requiring additional audit effort in order to maintain the same quality of service provided by Deloitte. Alternatively, the result may be driven by the subsequent auditor exercising monopoly power to extract rents from the client when there are no viable auditor alternatives. ${ }^{29}$

Whether the fee increases are the result of efficiency losses or monopoly pricing power, the implications of this finding is relevant to European regulators considering a

\footnotetext{
${ }^{28}$ Economic significance of fee differential (Table 7 - Panel B - Column 1): $\exp \left(\beta 2+\beta 3(\text { Median(Deloitte }(\text { Log_OtherandIT_Fees_01 }))_{3}\right)=\exp (-0.349+0.036(10.955))=1.0464$ ${ }^{29}$ Alternatively, the increase in audit fees for Deloitte's joint service switchers may have resulted from the degree of pre-SOX audit fee low-balling. Prior research suggests that in the pre-SOX environment accounting firms were willing to be "loss leaders" for audit services (Hillison et al., 1988) and lowball audit fees in order to secure lucrative consulting contracts. The degree of audit fee lowballing was likely dependent on the value accounting firms placed on these consulting contracts. If Deloitte's joint service switchers were more likely to contain high value consulting clients, then they should have received a larger discount in audit fees before SOX, and experienced a larger increase in audit fees after SOX. The implications of my findings for $\mathrm{H} 4$ would be less worrisome for regulators if the increase was a result of pre-SOX low-balling. To ensure that my results are not driven by the pre-SOX level of audit fees charged by Deloitte, I include the pre-switch level of audit fees (Log_Audit_Fees $s_{i, 2002}$ and Log_Audit_Fees L $\left._{i, t-1}\right)$ as an additional control variable in models (2a) and (2b). After including this additional control variable, the $\beta_{3}$ coefficient remains positive and significant ( $p$-value $<0.10$ for a one-tailed test). Thus, pre-SOX audit fee low balling does not appear to explain the larger increase in audit fees for Deloitte's joint service switchers.
} 
SOX-like ban on the joint provision of audit and consulting services (EU, 2010). This finding suggests that government intervention into the market for audit and consulting services may result in the unintended consequence of higher audit fees. Regulators should further examine whether European joint service clients have viable, high-quality auditor alternatives before they consider enacting the proposed ban on jointly-provided audit and consulting services.

\subsection{Multivariate Analyses -Loss of Audit Quality}

H5 predicts that in addition to audit fee implications, Deloitte's joint service switchers may have also experienced losses in audit effectiveness. To the extent that the subsequent auditor did not have the expertise or incentives to maintain Deloitte's level of service, post-switch audit quality may have declined. I proxy for changes in audit quality by capturing post-switch changes in discretionary accruals, and post-switch incidences of accounting restatements. The results from these analyses (not tabulated) indicate that the interaction effect between Deloitte_Switch and OtherandIT_Fees_01 is not significantly $(\mathrm{p}>0.10)$ related to changes in discretionary accruals or subsequent restatements. Thus, the results do not support the prediction that Deloitte's joint service switchers were more likely to experience a post-switch decrease in audit quality. The lack of support for hypothesis 5 is somewhat predictable based on the findings supporting hypothesis 4 . Collectively, the analyses supporting H4 and H5 suggest that the subsequent auditor exerted more effort (as evidenced by higher audit fees) to maintain a high level of audit quality. 


\section{ROBUSTNESS TESTS AND ADDITIONAL ANALYSIS}

\subsection{Alternative Auditor Industry Specialization Measures}

The industry specialization (Ind_Spec) proxy captured in model (1) is based on national-level industry leadership. Francis et al. (2005) provide evidence that national and city-specific industry specialization jointly influence audit quality and pricing. Thus, I examine the influence of the alternative Ind_Spec measure (Joint_Ind_Spec) in Table 4. The results indicate a negative association between Deloitte_Switch and Joint_Ind_Spec $(p$-value $<0.10)$. Thus, the results are consistent across both measures of industry specialization.

The descriptive statistics in Table 2 reveal that, over the sample period, Deloitte had fewer industry specialist clients than their Big 4 competitors. Having fewer specialist clients in their client portfolio likely resulted in a lower proportion of Deloitte specialist switchers. To ensure that this feature of Deloitte's client composition is not the main factor driving the results in Table 4, I scaled Ind_Spec by the proportion of clients classified as specialists for that auditor in the given year. I construct the auditor adjusted industry specialist variable (Audadj_Ind_Spec) as follows: if the client is a specialist, then the variable is equal to the number of specialist clients in the auditor's client portfolio in that year divided by the auditor's full number of clients (as provided in Audit Analytics) during the same year; if the client is a non-specialist, the variable is equal to 0 . The results indicate a negative association between Deloitte_Switch and Audadj_Ind_Spec ( $p$ value $<0.10$ ) in Table 4 . Thus, the results continue to support $\mathrm{H} 1$ after adjusting for the full client composition of specialists for each auditor. 


\subsection{Alternative Consulting Likelihood Measures}

When an accounting firm assesses the likelihood that a joint service client will require consulting services in the future, they may consider the client's extended history of M\&A activity and debt/equity issuances beyond the prior year. Thus, as a robustness check, I identify M\&A and new issue activity over the previous three years (M\&A_Prior3years and NewIssue_Prior3years). The results in Table 5 remain significant when replacing $M \& A$ with $M \& A \_$Prior3years, but are become insignificant when replacing New_Issue with NewIssue_Prior3years. This suggests that the joint auditor/client decision to provide consulting rather than audit services takes into account the extended history of M\&A activity, but not the extended history of debt and equity issuances.

To the extent that auditors receive advanced notice about future M\&A and issuance activity, I also assess whether one-year ahead M\&A activity ( $M \& A \_$futureyear) and subsequent issues of debt and equity (NewIssue_futureyear) influence the switch decision. Surprisingly, when I replace NewIssue with NewIssue_futureyear in Table 5, the results provide more support for Hypothesis 3. The coefficient on Log_OtherandIT_Fees_01*NewIssue_futureyear becomes positive and significant ( $p$ value $<0.10$ ), and the coefficient on Dummy_OtherandIT_Fees_01* NewIssue_futureyear remains positive and significant ( $p$-value $<0.10)$. When I replace $M \& A$ with $M \& A \_$futureyear in Table 5, the results become insignificant. Thus, it appears that Deloitte and their clients can anticipate future debt and equity issues and base their switch decision on the expectation of future issues. On the other hand, future M\&A 
activity cannot be anticipated and the switch decision is not influenced by these future events.

Because growth opportunities are difficult to operationalize, I replace market to book $(M T B)$ with Tobin's Q in Table 5 - Panel D. Both measures have been used in prior studies to capture this construct. The results become insignificant when using Tobins $Q$ rather than $M T B$ as a proxy for growth opportunities. Thus, there is little support for $\mathrm{H} 3$ in regards to growth opportunities influencing the joint auditor/client decision to provide consulting rather than audit services.

As with industry specialization, the descriptive statistics in Table 2 uncover that Deloitte's client composition is different than its competitor's composition in regards to the Consult_Likelihood proxies. To ensure that these differences are not driving the results in Table 5, I scale Avg3_FCF and Avg3_MTB by the average of these variables for that auditor in the given year $\left(A u d A d j \_F C F\right.$ and $\left.A u d A d j \_M T B\right)$. In addition, I adjust $M \& A$ and New_Issue as follows: If $M \& A$ (New_Issue) equals 1 , then I divide the number of $M \& A$ (New Issue) clients in the auditor's client portfolio in that year by the auditor's full number of clients (provided in Audit Analytics) during the same year (AudAdj_M\&A and $\left.A u d A d j \_N e w I s s u e\right)$. If $M \& A$ and New_Issue are classified as 0 , then $A u d A d j \_M \& A$ and $A u d A d j \_N e w I s s u e$, continue to equal 0.

The results remain unchanged when replacing $A v g 3 \_F C F$ and $M \& A$ with AudAdj_FCF and $A u d A d j \_M \& A$, respectively. The results become more consistent with H3 when replacing New_Issue with AudAdj_NewIssue. In fact, the coefficient on AudAdj_NewIssue * Log_OtherandIT_fees_O1 becomes positive and significant ( $p$-value 
$<0.05)$. The results become insignificant when replacing Avg3_MTB with $A u d A d j \_M T B$. The alternate specifications reveal that the impact of growth opportunities $(M T B)$ may be an artifact of differential client compositions between Deloitte and its competitors.

\subsection{Alternate Control Sample}

As discussed in the empirical design section, the underlying composition of consulting services offered by Deloitte in 2001 was probably different than that offered by E\&Y and KPMG, because these firms had already agreed to spin off their consulting division in 2000. Thus, in 2001, PWC was the only Big 4 firm offering a similar menu of consulting services to their clients. Thus, I rerun tables 4 and 5 after dropping all E\&Y and KPMG firm-year observations. This procedure limits the control sample to PWC auditor switchers. In Table 4, the coefficient on Ind_Spec remains negative and significant, but the coefficient on OtherandIT_fees_O1 is no longer significant. Thus, H1 continues to be supported, but there is no longer support for H2. In Table 5, the inferences from all results remain unchanged. These findings are still consistent with $\mathrm{H} 3$. 


\section{CONCLUSION}

In this paper, I investigate factors influencing the joint auditor-client decision to maintain an audit or consulting relationship in the post-SOX environment. I exploit the SOX regulatory ban on auditor-provided consulting services and the anomalous decision by Deloitte to retain its consulting division to examine these factors. I provide evidence that auditors and their clients favor the consulting over the audit relationship when both services were historically provided and the client is likely to require consulting services in the future. Conversely, auditors and their clients are likely to favor the audit over the consulting relationship when the auditor is a specialist in the client's industry. I also report empirical evidence on audit effectiveness and efficiency in cases where the client chooses to maintain the consulting relationship and is forced to hire a new auditor. Although there was no impact on audit effectiveness, auditor switches reduced efficiency as evidenced by significantly higher audit fees. These findings may be of interest to European regulators considering a SOX-like ban on the joint provision of audit and consulting services. My results suggest that the proposed intervention could have adverse unintended consequences with respect to audit fees.

This study is likely the first in a line of papers that will examine how accounting firms and their clients adapted to the mandated separation between audit and consulting services. I examine the decision to continue the audit versus consulting relationship during a period when one accounting firm (Deloitte) and its joint service clients were forced to immediately choose which service to retain. Aspects of this decision may have changed since this period. Deloitte and their audit clients are now able to take a more 
deliberate approach when deciding to discontinue the audit and establish (or reestablish) the consulting relationship. In addition, the types of consulting services demanded may have changed in recent years. Finally, the Big 4 public accounting firms that spun-off their consulting divisions prior to the enactment of SOX are in the process of rebuilding their consulting practices. Future studies could examine whether the audit vs. consulting decisions of all Big 4 firms and their clients have changed since the period examined in my study.

Future research could also identify additional factors influencing the choice between audit and consulting services. I provide evidence that accounting firms and clients consider auditor industry specialization, the historical procurement of consulting services, and three factors influencing future consulting requirements (free cash flow, M\&A and New Issue Activity) when assessing which service is more valuable. The factors influencing the joint auditor/client decision are likely more extensive and interrelated than I can identify in a single study. 


\section{APPENDIX A \\ TIMELINE OF CONSULTING DIVISION SPINOFFS}

\section{- Arthur Andersen}

- Aug 7, 2000 - Andersen Consulting Goes Public

- Jan 1, 2001 - Andersen Consulting Changes Name to Accenture

- $\quad$ Ernst \& Young

- $\quad$ Feb 29, 2000 - Cap Gemini Agrees to Merge with E\&Y Consulting

- PricewaterhouseCoopers

- Sep 11, 2000 - HP Considers Acquiring PricewaterhouseCoopers' Consulting $\mathrm{Biz}$

- Nov 14, 2000 - HP Drops Bid for PwC Consulting

- Jul 30, 2002 - PwC Sold its Consulting Unit to IBM

- KPMG

- Feb 8, 2001 - KPMG Consulting Goes Public

- Nov 1, 2002 - KPMG Consulting Changes Name to BearingPoint

- BDO Seidman

- May 10, 2000 - BDO Spins Off Consulting Division and Renamed Firm Wavebend Solutions, LLC

\section{- Grant Thornton}

- Oct 25, 2000 - Grant Thornton Sold Consulting Practice to Hitachi Ltd. 


\section{APPENDIX B \\ EXAMPLES OF DELOITTE AUDITOR SWITCHES INDUCED BY THE JOINT AUDITOR-CLIENT DECISION TO CONTINUE THE CONSULTING RELATIONSHIP}

Excerpts from the CLOROX Inc. Audit Committee Report-

- The Audit Committee reported last year that, because of a consulting engagement between the Company and Deloitte Consulting, the engagement of Deloitte \& Touche LLP as the Company's auditors would be terminated unless Deloitte \& Touche LLP and Deloitte Consulting separated from each other before December 31, 2002. The proposed split between the two Deloitte organizations did not occur. The Audit Committee, therefore, dismissed Deloitte \& Touche LLP on February 15, 2003, after the review of the Company's financial statements for the quarter ended December 31, 2002 had been completed.

Excerpts from the AutoNation Inc. $8 K-$

- Effective as of May 6, 2003, AutoNation, Inc. ("AutoNation") appointed KPMG LLP ("KPMG") as its new independent public accountant. Effective as of May 5, 2003, AutoNation dismissed Deloitte \& Touche LLP ("D\&T") as its independent public accountant. The change was made following the recent announcement by D\&T that it had ended efforts to separate Deloitte Consulting, which provides certain non-audit consulting services to the Company that will become prohibited services for an audit firm to provide to its audit clients under the Sarbanes-Oxley Act of 2002 and the rules promulgated thereunder. 


\section{APPENDIX C}

\section{VARIABLE DEFINITIONS - Model (1)}

\section{Variable}

\section{Dependent Variable:}

Deloitte_Switch

\section{Independent Variables:}

Ind_Spec

OtherandIT_Fees

\section{Control Variables:}

Tenure

Disc_Accr

AA_Acqcity_Dummy

High_Litigation_Dummy

Regulated_Dummy

Disagree
Dummy variable equal to one if the predecessor auditor was Deloitte; zero if the predecessor auditor was any Big 4 firm other than Deloitte.

Dummy variable equal to one if the predecessor auditor is a national-level industry specialist; zero otherwise

(1) Log of the sum of 2001 Non-Audit Fees classified as Other or IT (Log_OtherandIT_Fees). (2) Ratio of the sum of 2001 Non-Audit Fees classified as Other or IT scaled by Total fees (Ratio_OtherandIT_Fees), (3) Dummy variable equal to one if the the sum of 2001 Non-Audit Fees classified as Other or IT is positive; zero otherwise (Dummy_OtherandIT_Fees)

The log of auditor tenure of predecessor auditor

Discretionary accruals using a cross-sectional variation of the Jones (1991) accruals estimation model modified by Dechow, Sloan, and Sweeney (1995)

Dummy variable equal to one if the audit firm purchased the Anderson office in that particular city; zero otherwise

Dummy variable equal to one if the firm operates in high risk industries identified as those with four digit SIC equal to 2833-2836 and 8731-8734 (Biotechnology), 3570-3577 and 7370-7374 (Computers) 3600-3674 (Electronics), and 5200-5961 (Retail)

Dummy variable equal to one if the firm operates in regulated industries identified as those with four digit SIC equal to 4810-4899

(Communication), 4910-4924 and 4930-4939 (Gas and electric), and 4940-4941 (Water)

Dummy variable equal to one if there was a disagreement with the predecessor auditor; zero otherwise 
Resigned

Merger

Internal_Control_Issue

Accounting_Issue

Audit_Opinion_Issue

Downgrade_Big4

Going_Concern

Log_Size

Liq

Leverage

LossYear
Dummy variable equal to one if the auditor resigned from the engagement; zero if the client dismissed the auditor

Dummy variable equal to one if the auditor switch was caused by a merger or acquisition; zero otherwise

Dummy variable equal to one if the auditor switch was accompanied with an internal control issue; zero otherwise

Dummy variable equal to one if the auditor switch was accompanied with disagreements about accounting principles or issued related to accounting treatments; zero otherwise

Dummy variable equal to one if the auditor switch was accompanied with questions regarding the veracity or applicability of previous or upcoming audit opinions; zero otherwise

Dummy Variable equal to one if the client switched from a Big 4 accounting firm to a non-Big 4 accounting firm (downgrade); zero if the client switched for a Big 4 accounting firm to another Big 4 accounting firm (within-class)

Dummy Variable equal to one if the client received a going concern modified opinion in the year of the auditor switch or the prior year; zero otherwise

The natural $\log$ of the market value of equity

Ratio of current assets to current liabilities

Ratio of long term debt to total assets

Dummy variable equal to one if a firm has a net loss, zero otherwise 


\section{VARIABLE DEFINITIONS - Model (2)}

Variable

\section{Dependent Variable:}

Chg_Log_Audit_Fees

Independent Variables:

Deloitte_Switch

OtherandIT_Fees

\section{Control Variables:}

Chg_Log_Size

Chg_InvRec

Chg_ROA

Chg_Leverage

Downgrade_Big4

Chg_Segments

ICW

LossYear

\section{Definition}

The change in the log of audit fees

Same as Model (1)

Same as Model (1)

The change in the log of total assets

The change in the ratio of inventory plus receivables to total assets

The change in the ratio of net income to total assets

The change in the ratio of long term debt to total assets

Same as Model (1)

The change in the square root of the number of business segments

Dummy variable equal to one if the firm (or the auditor) indicates an internal control weakness in the year prior to the event or over the event period; zero otherwise. In model (2a), the event period is 2002 to 2004. In model (2b), the event period is time $t-1$ to $t$

Dummy variable equal to one if the firm (or the auditor) has a loss year in the year prior to the event or over the event period; zero otherwise. In model (2a), the event period is 2002 to 2004 . In model (2b), the event period is time $\mathrm{t}-1$ to $\mathrm{t}$ 


\section{APPENDIX D}

\section{CONTROL VARIABLE INCLUSION RATIONALE}

I included control variables in model (1) that could influence the likelihood of an auditor switch, the procurement of non-audit services, and the relationship between the two. I do not provide a prediction for any of the control variables because prior literature has not examined differences in the types of clients audited by Deloitte as compared to the other Big 4 auditors before SOX. To the extent that there are dissimilarities between these audit clients, the control variables should help account for these differences.

Beck et al., (1988) provide evidence that auditor tenure is longer and less variable when the client purchases a high level of non-audit services from the auditor. Thus, to the extent that Deloitte switches are characterized by longer or shorter tenure (Tenure), the level of non audit services is likely influenced by this determinant. Thus, I include the log of tenure of the predecessor auditor as a control variable.

In order to capture the influence of audit and financial reporting quality on auditor switches, I control for the level of discretionary accruals (Disc_Accr) in the year before the auditor switch. Defond et al., (1998) provide evidence that discretionary accruals are income decreasing in the year before an auditor switch, especially among firms with greater litigation risk. Thus, firms with high litigation risk may switch away from more conservative auditors in the hope of finding a more lenient successor. To the extent that Deloitte switches were characterized by differential levels of discretionary accruals, the decision to switch may have been influenced by Deloitte's relative conservatism. I 
measured discretionary accruals using a cross-sectional variation of the Jones, (1991) accruals estimation model modified by Dechow, Sloan, and Sweeney, (1995).

The decision to switch may have also been influenced by resource constraints due to the influx of new Andersen clients, particularly for firm-offices that absorbed the Andersen office in that city (Kohlbeck et al., 2008; Landsman et al., 2009). Thus, I include a dummy variable equal to one if the audit firm purchased the Andersen office in that particular city; zero otherwise ${ }^{30}$ (AA_acqcity_dummy). Since Deloitte was active in absorbing former Andersen offices and clients, they may have experienced more auditor switches than their competitors due to capacity constraints.

Prior literature has identified differences in auditor switches and audit fees depending on the client's industry, specifically, if the client belongs to a high-litigation ${ }^{31}$ (High_Litigation_Dummy) or a regulated ${ }^{32}$ industry (Regulated_Dummy). Firms in high litigation environments are more likely to be dropped by their auditor (Krishnan et al. 1997) especially after Enron, Worldcom, the downfall of Andersen, and the passage of SOX. The fear of catastrophic lawsuits may have induced Deloitte to drop their more risky audit clients. Regulated industries have high levels of standardization and extensive external monitoring by parties other than the auditor (Dunn et. al. 2004). Thus, clients in these industries may be of relatively lower risk than unregulated clients. More importantly for this study, regulated industries are more likely to have one or two auditors dominate the market (Danos et al. 1982). As a result, the presence of an auditor

\footnotetext{
${ }^{30}$ I obtained this office purchase information from Table 2 of Kohlbeck et al (2008).

${ }^{31}$ High_Litigation_Dummy is equal to one if the firm operates in high risk industries identified as those with four digit SIC equal to 2833-2836 and 8731-8734 (Biotechnology), 3570-3577 and 7370-7374 (Computers) 3600-3674 (Electronics), and 5200-5961 (Retail). ${ }^{32}$ Regulated_Dummy is equal to one if the firm operates in regulated industries identified as those with four digit SIC equal to 48104899 (Communication), 4910-4924 and 4930-4939 (Gas and electric), and 4940-4941 (Water). Financial Institutions are not classified as regulated because they are eliminated from the sample.
} 
industry specialist is more likely in regulated industries. Although this dichotomy between regulated and unregulated industries is less pronounced in recent years (Hogan et al., 1999), the relationship between industry specialization and the likelihood of a switch may be influenced by Deloitte's relatively high level of activity in regulated markets. To the extent that there are other industry-specific factors influencing the relationship between the dependent and independent variables of interest, I also include industry fixed effects (INDDUM) in the model.

An advantage of my research design is that I can identify disclosed auditor/client disagreements, accounting issues, and other events that caused or influenced the decision to switch auditors. These disagreements and issues are not disclosed when the client retains its predecessor auditor. In the model, I identify whether the auditor switch was caused by a disagreement with the predecessor auditor (Disagree), caused by a merger or acquisition (Merger), accompanied with an internal control issue (Internal_Control_Issue), accompanied with disagreements about accounting principles or issues related to accounting treatments (Accounting_Issue), accompanied with questions regarding the veracity or applicability of previous or upcoming audit opinions (Audit_Opinion_Issue), or preceded by a modified going concern opinion in the current or previous year (Going_Concern). To the extent that Deloitte's switches were more or less likely to be affected by these issues and disagreements, these indicator variables should control for these differences.

As discussed in the introduction, the decision to discontinue the audit in order to maintain the consulting relationship is a joint auditor/client decision. Thus, the switch 
decision can either be made by the auditor through a resignation or by the client through a dismissal. Nevertheless, prior literature provides evidence that there are other auditor and client factors that influence whether the change is a resignation or a dismissal. For example, Shu, (2000) finds that auditor resignation is positively related to increased client legal exposure, and to clientele mismatch. Krishnan et al., (1997) similarly find that auditor resignation is positively associated with auditor litigation risk. Thus, I include a dummy variable equal to one if the auditor resigned from the engagement; zero if the client dismissed the auditor (Resigned).

Prior research provides evidence that clients were more likely to switch from a Big 4 auditor to a non-Big 4 auditor after the enactment of SOX because of client concerns about fee increases (Ettredge et al., 2007), and auditor concerns about client risk (Landsman et al., 2009). In addition, firms switching from a Big-4 firm to a Non-Big 4 firm were more likely to be smaller companies, companies with going-concern reports, and companies that later reported material weaknesses in their internal controls (Ettredge et al., 2007). To control for the differences between lateral and downgrade switchers, I included a dummy variable equal to one if the client switched from a Big 4 accounting firm to a non-Big 4 accounting firm (downgrade); zero if the client switched for a Big 4 accounting firm to another Big 4 accounting firm (lateral).

Other possible differences between the financial characteristics of Deloitte switchers and non-Deloitte switchers, may also impact the probability of a switch. The client characteristics I control for include Log_Size, Liquidity, Leverage, and the presence 
of a loss in the current or prior year (Loss). Finally, to control for possible differences between audit switches in 2003 and 2004, I include year fixed effects. 


\section{APPENDIX E TABLES}

Table $1 \quad$ Sample Selection........................................... 71

Table 2 Descriptive Statistics - Model (1).......................... $\quad 72$

Table 3 Correlation Table.......................................... 74

Table 4 Regression of the Probability of Deloitte Switch (vs. non-Deloitte

Switch) on the Historical Reliance on Auditor-Provided Consulting

Services, and Auditor Industry Specialization................... 75

Table 5 Regression of the Probability of Deloitte Switch (vs. non-Deloitte

Switch) on the interaction between the Historical Reliance on Auditor-

Provided Consulting Services and the Likelihood the Client will

Require Consulting Services................................ 76

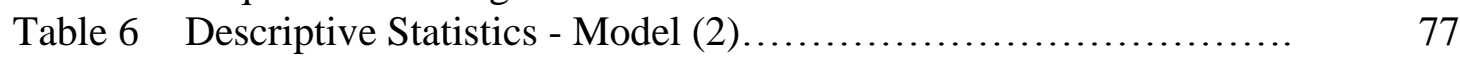

Table 7 Regression of the Change in Audit Fees on the interaction of the

Probability of Deloitte Switch (vs. non-Deloitte Switch) and the

Historical Reliance on Auditor-Provided Consulting Services...... 
Table 1

Sample Selection

All firm-year observations in the intersection of Compustat and

Audit Analytics from 2002 - 2004 with positive Audit Fees

25,279

Less firm-year observations with:

Financial firms

No Auditor Changes - 7/30/2002 to 2004

$(17,423)$

Non-Big 4 Auditor Switch

Missing 2001 Audit Analytic Data

2001 Auditor not the same as Dismissed/Resigned Auditor

Missing data to compute regression variables

Total firm-year observations

421 
Table 2

Descriptive Statistics

\section{Panel A - Independent Variables of Interest - Full Population (Switchers and Non-Switchers)}

Historical Dependence on Auditor Provided Consultancy Services - 2001

\begin{tabular}{|c|c|c|c|c|c|c|c|c|c|c|c|c|c|c|}
\hline & \multicolumn{4}{|c|}{$\underline{\text { Full Sample }}$} & \multicolumn{4}{|c|}{ Deloitte Sample } & \multicolumn{4}{|c|}{ Non-Deloitte Sample } & \multirow[b]{2}{*}{$\underline{t}$-statistic } & \multirow[b]{2}{*}{$\underline{\text { Wilcoxon Z }}$} \\
\hline & $\underline{\mathbf{N}}$ & $\underline{\text { Mean }}$ & $\underline{\text { Median }}$ & $\underline{\text { Std. Dev }}$ & $\underline{\mathbf{N}}$ & $\underline{\text { Mean }}$ & $\underline{\text { Median }}$ & $\underline{\text { Std. Dev }}$ & $\underline{\mathbf{N}}$ & $\underline{\text { Mean }}$ & $\underline{\text { Median }}$ & $\underline{\text { Std. Dev }}$ & & \\
\hline OtherandIT_fees & 4,859 & 706,422 & 58,350 & $3,436,576$ & 1,002 & 790,809 & 60,615 & $3,489,168$ & 3,857 & 684,499 & 57,937 & $3,422,898$ & 0.86 & 0.78 \\
\hline Log_OtherandIT_fees & 4,859 & 8.875 & 10.974 & 5.312 & 1,002 & 9.086 & 11.012 & 5.211 & 3,857 & 8.820 & 10.967 & 5.337 & 1.43 & 0.78 \\
\hline Dummy_OtherandIT_fees & 4,859 & 0.757 & 1.000 & 0.429 & 1,002 & 0.774 & 1.000 & 0.418 & 3,857 & 0.752 & 1.000 & 0.432 & 1.51 & 1.48 \\
\hline Ratio_OtherandIT_fees & 4,859 & 0.28 & 0.23 & 0.25 & 1,002 & 0.29 & 0.25 & 0.26 & 3,857 & 0.28 & 0.23 & 0.25 & 1.62 & 1.53 \\
\hline \multicolumn{15}{|c|}{ Lag Industry Specialization and Likelihood of Future Consulting Work Proxies } \\
\hline Ind_Spec & 9,159 & 0.424 & 0.000 & 0.494 & 2,058 & 0.354 & 0.000 & 0.478 & 7,101 & 0.444 & 0.000 & 0.497 & $-7.47 * * *$ & $-7.30^{* * *}$ \\
\hline$A v g 3 \_F C F$ & 8,039 & 93.795 & 5.337 & 360.292 & 1,791 & 78.979 & 7.110 & 308.667 & 6,248 & 98.042 & 4.969 & 373.693 & $-2.19 * *$ & $2.35^{* *}$ \\
\hline$M \& A$ & 9,088 & 0.060 & 0.000 & 0.238 & 2,031 & 0.053 & 0.000 & 0.224 & 7,057 & 0.062 & 0.000 & 0.242 & -1.62 & -1.55 \\
\hline New_Issue & 8,256 & 0.649 & 1.000 & 0.477 & 1,819 & 0.676 & 1.000 & 0.468 & 6,437 & 0.641 & 1.000 & 0.480 & $2.83^{* * *}$ & $2.79 * * *$ \\
\hline Avg3_MTB & 7,363 & 2.769 & 1.982 & 5.455 & 1,575 & 2.544 & 1.821 & 4.801 & 5,788 & 2.830 & 2.037 & 5.618 & $-2.02 * *$ & $-5.21 * * *$ \\
\hline
\end{tabular}

Panel B - Independent Variables of Interest - Reduced Sample (Switchers Only)

Log_OtherandIT_fees_OI
Dummy_OtherandIT_fees_O1
Ratio_OtherandIT_fees_O1
Ind_Spec
Avg3_FCF
M\&A
New_Issue
Avg3_MTB

\begin{tabular}{|c|c|c|c|c|c|c|c|}
\hline \multicolumn{4}{|c|}{ Full Sample } & \multicolumn{4}{|c|}{ Deloitte Sample } \\
\hline$\underline{\mathbf{N}}$ & $\underline{\text { Mean }}$ & $\underline{\text { Median }}$ & $\underline{\text { Std. Dev }}$ & $\underline{\mathbf{N}}$ & Mean & $\underline{\text { Median }}$ & $\underline{\text { Std. Dev }}$ \\
\hline 421 & 9.041 & 10.968 & 4.899 & 90 & 9.750 & 11.200 & 4.257 \\
\hline 421 & 0.791 & 1.000 & 0.407 & 90 & 0.856 & 1.000 & 0.354 \\
\hline 421 & 0.28 & 0.25 & 0.24 & 90 & 0.31 & 0.28 & 0.24 \\
\hline 421 & 0.361 & 0.000 & 0.481 & 90 & 0.289 & 0.000 & 0.456 \\
\hline 413 & 17.518 & $(0.407)$ & 167.322 & 88 & 9.659 & $(0.016)$ & 73.040 \\
\hline 421 & 0.038 & 0.000 & 0.191 & 90 & 0.022 & 0.000 & 0.148 \\
\hline 389 & 0.573 & 1.000 & 0.495 & 80 & 0.588 & 1.000 & 0.495 \\
\hline 414 & 2.523 & 1.677 & 6.404 & 86 & 1.144 & 1.353 & 4.388 \\
\hline
\end{tabular}

\begin{tabular}{lrrr} 
& \multicolumn{3}{l}{ Non-Deloitte Sample } \\
$\mathbf{N}$ & $\underline{\text { Mean }}$ & $\underline{\text { Median }}$ & $\underline{\text { Std. Dev }}$ \\
331 & 8.848 & 10.913 & 5.048 \\
331 & 0.773 & 1.000 & 0.419 \\
331 & 0.27 & 0.24 & 0.24 \\
331 & 0.381 & 0.000 & 0.486 \\
325 & 19.646 & $(0.603)$ & 184.789 \\
331 & 0.042 & 0.000 & 0.202 \\
309 & 0.570 & 1.000 & 0.496 \\
328 & 2.885 & 1.747 & 6.795
\end{tabular}

$\underline{t}$-statistic

Wilcoxon Z

$1.71 *$
$1.87 *$
1.31
$-1.67 *$
-0.78
-1.05
0.29
$-2.88^{*} * *$


Table 2 (cont)

Descriptive Statistics

\begin{tabular}{|c|c|c|c|c|c|c|c|c|c|c|c|c|c|c|}
\hline \multicolumn{15}{|c|}{ Panel C - Control Variables - Reduced Sample (Switchers Only) } \\
\hline & \multicolumn{4}{|c|}{ Full Sample } & \multicolumn{4}{|c|}{$\underline{\text { Deloitte Sample }}$} & \multicolumn{4}{|c|}{$\underline{\text { Non-Deloitte Sample }}$} & \multirow[b]{2}{*}{$\underline{t}$-statistic } & \multirow[b]{2}{*}{$\underline{\text { Wilcoxon Z }}$} \\
\hline & $\underline{\mathbf{N}}$ & $\underline{\text { Mean }}$ & $\underline{\text { Median }}$ & $\underline{\text { Std. Dev }}$ & $\underline{\mathbf{N}}$ & $\underline{\text { Mean }}$ & $\underline{\text { Median }}$ & $\underline{\text { Std. Dev }}$ & $\underline{\mathbf{N}}$ & $\underline{\text { Mean }}$ & $\underline{\text { Median }}$ & $\underline{\text { Std. Dev }}$ & & \\
\hline Tenure & 421 & 2.033 & 2.197 & 0.681 & 90 & 1.983 & 2.197 & 0.785 & 331 & 2.046 & 2.197 & 0.650 & -0.70 & -0.17 \\
\hline Log_Size & 421 & 4.003 & 3.895 & 2.008 & 90 & 4.027 & 3.775 & 1.866 & 331 & 3.996 & 3.965 & 2.047 & 0.14 & 0.00 \\
\hline Liq & 421 & 2.77 & 1.87 & 3.20 & 90 & 2.55 & 1.88 & 2.22 & 331 & 2.83 & 1.87 & 3.41 & -0.95 & -0.26 \\
\hline Leverage & 421 & 0.531 & 0.160 & 2.272 & 90 & 0.360 & 0.205 & 1.891 & 331 & 0.577 & 0.152 & 2.366 & -0.91 & 0.12 \\
\hline LossYear & 421 & 0.743 & 1.000 & 0.437 & 90 & 0.644 & 1.000 & 0.481 & 331 & 0.770 & 1.000 & 0.421 & $-2.26 * *$ & $-2.42 * *$ \\
\hline Disc_Accr & 421 & $(0.011)$ & $(0.010)$ & 0.457 & 90 & $(0.031)$ & $(0.004)$ & 0.318 & 331 & $(0.005)$ & $(0.015)$ & 0.488 & -0.60 & 0.82 \\
\hline AA_Acqcity_Dummy & 421 & 0.086 & 0.000 & 0.280 & 90 & 0.111 & 0.000 & 0.316 & 331 & 0.079 & 0.000 & 0.269 & 0.89 & 0.98 \\
\hline High_Litigation_Dummy & 421 & 0.565 & 1.000 & 0.496 & 90 & 0.433 & 0.000 & 0.498 & 331 & 0.601 & 1.000 & 0.490 & $-2.84 * * *$ & $-2.84 * * *$ \\
\hline Regulated_Dummy & 421 & 0.128 & 0.000 & 0.335 & 90 & 0.144 & 0.000 & 0.354 & 331 & 0.124 & 0.000 & 0.330 & 0.50 & 0.52 \\
\hline Going_Concern & 421 & 0.147 & 0.000 & 0.355 & 90 & 0.133 & 0.000 & 0.342 & 331 & 0.151 & 0.000 & 0.359 & -0.43 & -0.42 \\
\hline Downgrade_Big4 & 421 & 0.710 & 1.000 & 0.454 & 90 & 0.667 & 1.000 & 0.474 & 331 & 0.722 & 1.000 & 0.449 & -0.99 & -1.03 \\
\hline Disagree & 421 & 0.173 & 0.000 & 0.379 & 90 & 0.167 & 0.000 & 0.375 & 331 & 0.175 & 0.000 & 0.381 & -0.19 & -0.19 \\
\hline Resigned & 421 & 0.297 & 0.000 & 0.457 & 90 & 0.233 & 0.000 & 0.425 & 331 & 0.314 & 0.000 & 0.465 & -1.57 & -1.49 \\
\hline Merger & 421 & 0.005 & 0.000 & 0.069 & 90 & 0.011 & 0.000 & 0.105 & 331 & 0.003 & 0.000 & 0.055 & 0.70 & 0.98 \\
\hline Internal_Control_Issue & 421 & 0.138 & 0.000 & 0.345 & 90 & 0.100 & 0.000 & 0.302 & 331 & 0.148 & 0.000 & 0.356 & -1.29 & -1.17 \\
\hline Accounting_Issue & 421 & 0.033 & 0.000 & 0.180 & 90 & 0.056 & 0.000 & 0.230 & 331 & 0.027 & 0.000 & 0.163 & 1.10 & 1.33 \\
\hline Audit_Opinion_Issue & 421 & 0.026 & 0.000 & 0.160 & 90 & 0.022 & 0.000 & 0.148 & 331 & 0.027 & 0.000 & 0.163 & -0.28 & -0.26 \\
\hline
\end{tabular}


Table 3

Correlation Table: Pearson (Spearman) Correlations are Presented in the Upper (Lower) Diagonal

\begin{tabular}{|c|c|c|c|c|c|c|c|c|}
\hline \multirow{2}{*}{ Log_OtherandIT_fees_01 (Log_Fees_01) } & Log_Fees_01 & $\begin{array}{r}\text { Dummy_Fees_01 } \\
\mathbf{0 . 9 4 9 8 8}\end{array}$ & $\begin{array}{r}\text { Ratio_Fees_01 } \\
\mathbf{0 . 7 4 9 3 5}\end{array}$ & $\begin{array}{r}\text { Ind_Spec } \\
0.05567\end{array}$ & $\begin{array}{r}A v g 3_{2} F C F \\
\mathbf{0 . 1 4 6 1 9}\end{array}$ & $\begin{array}{l}M \& A \\
-0.0658\end{array}$ & $\begin{array}{r}\text { New_Issue } \\
\mathbf{0 . 0 8 9 1 2}\end{array}$ & $\begin{array}{r}A v g 3 \_M T B \\
-0.00264\end{array}$ \\
\hline & & $<.0001$ & $<.0001$ & 0.2544 & 0.0029 & 0.1778 & 0.0792 & 0.9572 \\
\hline \multirow{2}{*}{ Dummy_OtherandIT_fees_01 (Dummy_Fees_01) } & 0.7055 & & 0.5994 & 0.03371 & 0.06184 & -0.08113 & 0.0708 & 0.02654 \\
\hline & $<.0001$ & & $<.0001$ & 0.4903 & 0.2098 & 0.0964 & 0.1634 & 0.5902 \\
\hline \multirow{2}{*}{ Ratio_OtherandIT_fees_01 (Ratio_Fees_01) } & 0.87887 & 0.7055 & & 0.01511 & 0.07777 & -0.03008 & 0.00558 & 0.00279 \\
\hline & $<.0001$ & $<.0001$ & & 0.7572 & 0.1145 & 0.5382 & 0.9127 & 0.9549 \\
\hline \multirow{2}{*}{ Ind_Spec } & 0.05053 & 0.03371 & 0.01897 & & 0.11045 & -0.07182 & -0.01673 & -0.06504 \\
\hline & 0.3009 & 0.4903 & 0.6979 & & 0.0248 & 0.1413 & 0.7422 & 0.1866 \\
\hline \multirow{2}{*}{$A v g 3 \_F C F$} & 0.10938 & 0.02388 & 0.05957 & 0.13036 & & -0.01183 & 0.03119 & 0.02628 \\
\hline & 0.0262 & 0.6284 & 0.2271 & 0.008 & & 0.8106 & 0.5439 & 0.5975 \\
\hline \multirow{2}{*}{$M \& A$} & -0.03548 & -0.08113 & -0.03564 & -0.07182 & 0.01813 & & 0.04784 & 0.00442 \\
\hline & 0.4678 & 0.0964 & 0.4658 & 0.1413 & 0.7134 & & 0.3467 & 0.9285 \\
\hline \multirow{2}{*}{ New_Issue } & 0.1006 & 0.0708 & 0.01451 & -0.01673 & 0.07285 & 0.04784 & & -0.0305 \\
\hline & 0.0474 & 0.1634 & 0.7754 & 0.7422 & 0.1558 & 0.3467 & & 0.5523 \\
\hline \multirow{2}{*}{$A v g 3 \_M T B$} & 0.05785 & 0.08529 & 0.09664 & -0.08694 & -0.02731 & 0.01866 & -0.10745 & \\
\hline & 0.2402 & 0.0831 & 0.0494 & 0.0772 & 0.5832 & 0.705 & 0.0358 & \\
\hline
\end{tabular}

This table presents the Pearson correlation coefficients on the top right quadrant, and the Spearman correlation coefficients on the bottom left quadrant. The P-Value is displayed below the correlation coefficient. Correlations significant at the $10 \%$ level are in bold. See Appendix A for variable definitions. 
Table 4

Regression of the Probability of Deloitte Switch (vs. non-Deloitte Switch) on the Historical Reliance on Auditor-Provided Consulting Services, and Auditor Industry Specialization

Model (1): Deloitte_Switch ${ }_{i, t}=\alpha+B_{1}($ OtherandIT_Fees_01 $)+\boldsymbol{B}_{2}\left(\right.$ Specialist $\left._{i, t-1}\right)+B_{k}\left(Z_{i, t \text { and } t-1}\right)+\varepsilon_{i, t}$

\begin{tabular}{|c|c|c|c|c|}
\hline \multirow{2}{*}{$\begin{array}{c}\text { Independent } \\
\text { Variables }\end{array}$} & \multirow{2}{*}{$\begin{array}{c}\text { Predicted } \\
\text { Sign } \\
\end{array}$} & \multicolumn{3}{|c|}{ Independent Variable of Interest } \\
\hline & & Log_OtherandIT_Fees_OI & Ratio_OtherandIT_Fees_OI & Dummy_OtherorIT_Fees_O1 \\
\hline \multirow{2}{*}{ Log_OtherandIT_Fees_01 } & + & 0.061 & & \\
\hline & & $(1.89)^{*}$ & & \\
\hline \multirow[t]{2}{*}{ Ratio_OtherandIT_Fees_01 } & + & & 0.857 & \\
\hline & & & $(1.46)$ & \\
\hline \multirow[t]{2}{*}{ Dummy_OtherorIT_Fees_01 } & + & & & 0.670 \\
\hline & & & & $(1.79)^{*}$ \\
\hline \multirow[t]{2}{*}{ Ind_Spec } & - & -0.771 & -0.744 & -0.760 \\
\hline & & $(-2.42)^{* *}$ & $(-2.34)^{* *}$ & $(-2.39)^{* *}$ \\
\hline \multirow[t]{2}{*}{ Tenure } & $?$ & -0.228 & -0.204 & -0.226 \\
\hline & & $(-1.10)$ & $(-0.99)$ & $(-1.08)$ \\
\hline \multirow[t]{2}{*}{ Log_Size } & $?$ & -0.114 & -0.102 & -0.090 \\
\hline & & $(-1.18)$ & $(-1.06)$ & $(-0.94)$ \\
\hline \multirow[t]{2}{*}{ Liq } & $?$ & -0.062 & -0.069 & -0.062 \\
\hline & & $(-1.09)$ & $(-1.21)$ & $(-1.10)$ \\
\hline \multirow[t]{2}{*}{ Leverage } & $?$ & -0.086 & -0.089 & -0.086 \\
\hline & & $(-1.28)$ & $(-1.29)$ & $(-1.29)$ \\
\hline \multirow[t]{2}{*}{ LossYear } & $?$ & -0.441 & -0.435 & -0.417 \\
\hline & & $(-1.28)$ & $(-1.26)$ & $(-1.21)$ \\
\hline \multirow[t]{2}{*}{ Disc_Accr } & $?$ & -0.232 & -0.282 & -0.230 \\
\hline & & $(-0.68)$ & $(-0.83)$ & $(-0.66)$ \\
\hline \multirow[t]{2}{*}{ AA_Acqcity_Dummy } & $?$ & 0.201 & 0.167 & 0.185 \\
\hline & & $(0.41)$ & $(0.34)$ & $(0.38)$ \\
\hline \multirow[t]{2}{*}{ Downgrade_Big4 } & $?$ & -0.215 & -0.237 & -0.245 \\
\hline & & $(-0.58)$ & $(-0.64)$ & $(-0.66)$ \\
\hline \multirow[t]{2}{*}{ High_Litigation_Dummy } & $?$ & -0.872 & -0.833 & -0.866 \\
\hline & & $(-1.63)$ & $(-1.56)$ & $(-1.62)$ \\
\hline \multirow[t]{2}{*}{ Regulated_Dummy } & $?$ & 1.074 & 1.154 & 1.039 \\
\hline & & $(1.59)$ & $(1.70) *$ & $(1.53)$ \\
\hline \multirow[t]{2}{*}{ Going_Concern } & $?$ & -0.145 & -0.167 & -0.119 \\
\hline & & $(-0.33)$ & $(-0.38)$ & $(-0.27)$ \\
\hline \multirow[t]{2}{*}{ Disagree } & $?$ & 0.736 & 0.774 & 0.703 \\
\hline & & $(0.99)$ & $(1.04)$ & $(0.95)$ \\
\hline \multirow[t]{2}{*}{ Resigned } & $?$ & -0.209 & -0.165 & -0.199 \\
\hline & & $(-0.62)$ & $(-0.49)$ & $(-0.59)$ \\
\hline \multirow[t]{2}{*}{ Merger } & $?$ & 2.051 & 1.944 & 1.993 \\
\hline & & $(1.32)$ & $(1.25)$ & $(1.29)$ \\
\hline \multirow[t]{2}{*}{ Internal_Control_issue } & $?$ & -0.948 & -0.947 & -0.915 \\
\hline & & $(-1.19)$ & $(-1.19)$ & $(-1.15)$ \\
\hline \multirow[t]{2}{*}{ Accounting_Issue } & $?$ & 1.035 & 1.015 & 1.109 \\
\hline & & $(1.15)$ & $(1.12)$ & $(1.23)$ \\
\hline Audit_Opinion_Issue & $?$ & -1.228 & -1.188 & -1.288 \\
\hline & & $(-1.15)$ & $(-1.11)$ & $(-1.20)$ \\
\hline Industry and Year Fixed Effects & & Yes & Yes & Yes \\
\hline Pseudo- $\mathrm{R}^{2}$ & & 0.1301 & 0.1261 & 0.1291 \\
\hline Observations & & 421 & 421 & 421 \\
\hline
\end{tabular}


Table 5

Regression of the Probability of Deloitte Switch (vs. non-Deloitte Switch) on the interaction between the Historical Reliance on Auditor-Provided Consulting Services and the Likelihood the Client will Require Consulting Services

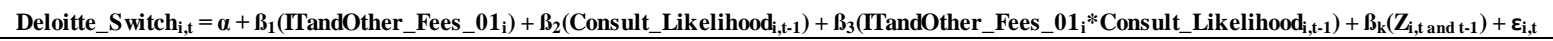

Panel A. Consult_Likelihood - Free Cash Flow

\begin{tabular}{|c|c|c|c|c|}
\hline \multirow{2}{*}{$\begin{array}{c}\text { Independent } \\
\text { Variables }\end{array}$} & \multirow{2}{*}{$\begin{array}{l}\text { Predicted } \\
\text { Sign }\end{array}$} & \multicolumn{3}{|c|}{ Independent Variable of Interest } \\
\hline & & Log_OtherandIT_Fees_01 & Ratio_OtherandIT_Fees_OI & Dummy_OtherorIT_Fees_O1 \\
\hline \multirow{2}{*}{ OtherandIT_Fees_01 } & + & 0.088 & 0.923 & 1.294 \\
\hline & & $(2.50) * *$ & $(1.45)$ & $(2.95) * * *$ \\
\hline \multirow[t]{2}{*}{ Avg3_FCF } & - & -0.029 & -0.006 & -0.068 \\
\hline & & $(-2.73) * * *$ & $(-1.36)$ & $(-3.34) * * *$ \\
\hline \multirow[t]{2}{*}{ OtherandIT_Fees_01*Avg3_FCF } & + & 0.002 & 0.009 & 0.068 \\
\hline & & $(2.77)^{* * * *}$ & $(1.30)$ & $(3.33)^{* * * *}$ \\
\hline Pseudo- $\mathrm{R}^{2}$ & & 0.1496 & 0.1327 & 0.1683 \\
\hline Observations & & 413 & 413 & 413 \\
\hline
\end{tabular}

Panel B. Consult_Likelihood - Mergers and Acquisitions

\begin{tabular}{|c|c|c|c|c|}
\hline \multirow{2}{*}{$\begin{array}{l}\text { Independent } \\
\text { Variables }\end{array}$} & \multirow{2}{*}{$\begin{array}{l}\text { Predicted } \\
\text { Sign }\end{array}$} & \multicolumn{3}{|c|}{ Independent Variable of Interest } \\
\hline & & Log_OtherandIT_Fees_01 & Ratio_OtherandIT_Fees_01 & Dummy_OtherorIT_Fees_01 \\
\hline \multirow[t]{2}{*}{ OtherandIT_Fees_01 } & + & 0.056 & 0.585 & 0.590 \\
\hline & & $(1.60)$ & $(0.91)$ & $(1.51)$ \\
\hline \multirow[t]{2}{*}{$M \& A$} & - & -3.101 & -1437.755 & -12.536 \\
\hline & & $(-2.00) * *$ & $(-15.59) * * *$ & $(-16.50) * * *$ \\
\hline \multirow[t]{2}{*}{ OtherandIT_Fees_01*M\&A } & + & 0.280 & 2717.240 & 12.842 \\
\hline & & $(2.15)^{* *}$ & $(15.58)^{* * * *}$ & $(11.56)^{* * * *}$ \\
\hline Pseudo- $\mathrm{R}^{2}$ & & 0.1323 & 0.15 & 0.1317 \\
\hline Observations & & 421 & 421 & 421 \\
\hline
\end{tabular}

Panel C. Consult_Likelihood - Debt and Equity Offerings

\begin{tabular}{|c|c|c|c|c|}
\hline \multirow{2}{*}{$\begin{array}{c}\text { Independent } \\
\text { Variables }\end{array}$} & \multirow{2}{*}{$\begin{array}{c}\text { Predicted } \\
\text { Sign }\end{array}$} & \multicolumn{3}{|c|}{ Independent Variable of Interest } \\
\hline & & Log_OtherandIT_Fees_01 & Ratio_OtherandIT_Fees_01 & Dummy_OtherorIT_Fees_01 \\
\hline \multirow[t]{2}{*}{ OtherandIT_Fees_01 } & + & 0.005 & 0.326 & -0.038 \\
\hline & & $(0.11)$ & $(0.34)$ & $(-0.07)$ \\
\hline \multirow[t]{2}{*}{ New_Issues } & - & -1.125 & -0.248 & -1.454 \\
\hline & & $(-1.53)$ & $(-0.52)$ & $(-1.75) *$ \\
\hline \multirow[t]{2}{*}{ OtherandIT_Fees_01*New_Issues } & + & 0.111 & 0.755 & 1.640 \\
\hline & & $(1.62)$ & $(0.62)$ & $(1.85)^{*}$ \\
\hline Pseudo- $\mathrm{R}^{2}$ & & 0.1402 & 0.1308 & 0.1425 \\
\hline Observations & & 389 & 389 & 389 \\
\hline
\end{tabular}

Panel D. Consult_Likelihood - Growth Opportunies proxied with Market to Book ratio

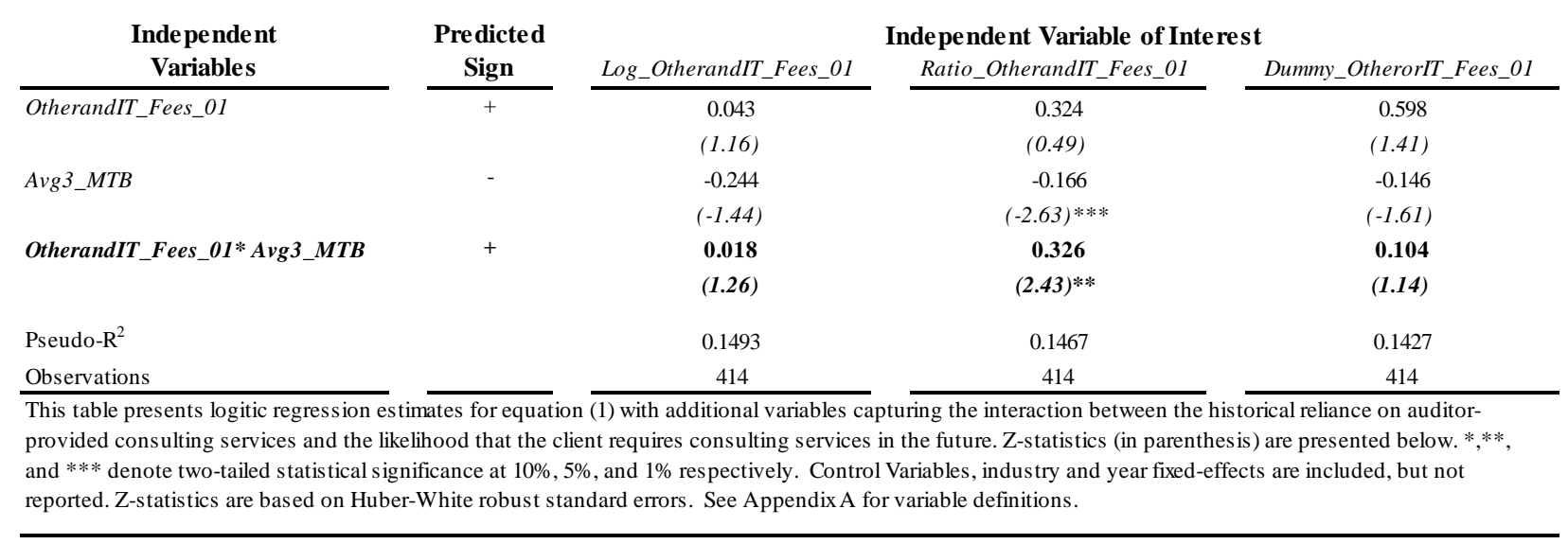


Table 6

Descriptive Statistics - Model (2)

Panel A - Changes in Audit Fees (2004 - 2002)

\begin{tabular}{lrrrr} 
& \multicolumn{3}{c}{ Full Sample (n=378) } \\
& $\underline{\text { Mean }}$ & Median & Std. Dev \\
\cline { 4 - 4 } Deloitte_Switch & 0.193 & 0.000 & 0.395 \\
Chg_Log_Audit_Fees & $(0.010)$ & 0.096 & 0.953 \\
Log_OtherandIT_Fees & 9.026 & 10.943 & 4.899 \\
Ratio_OtherandIT_Fees & 0.273 & 0.238 & 0.240 \\
Dummy_OtherandIT_Fees & 0.788 & 1.000 & 0.409 \\
Chg_Log_Size & 0.04 & 0.06 & 0.53 \\
Chg_InvRec & $(0.003)$ & 0.000 & 0.105 \\
Chg_ROA & 0.006 & 0.016 & 0.782 \\
Chg_Leverage & 0.074 & 0.016 & 0.706 \\
Downgrade_Big4 & $(0.556)$ & $(1.000)$ & 0.498 \\
Chg_Segments & 0.334 & 0.318 & 0.454 \\
ICW & 0.090 & 0.000 & 0.286 \\
LossYear & 0.762 & 1.000 & 0.426 \\
\hline
\end{tabular}

Deloitte Sample (n=73)

Non-Deloitte Sample (n=305)

Mean Median Std. Dev

Mean Median $\underline{\text { Std. Dev }}$

$\begin{array}{lll}(0.003) & 0.178 \quad 0.947\end{array}$

$9.809 \quad 11.225 \quad 4.197$

$0.292 \quad 0.237 \quad 0.231$

$\begin{array}{lll}0.863 & 1.000 \quad 0.346\end{array}$

$\begin{array}{lll}0.07 & 0.10 \quad 0.57\end{array}$

$\begin{array}{lll}0.007 & 0.006 & 0.109\end{array}$

(0.116) $0.011 \quad 1.062$

$\begin{array}{lll}0.047 & 0.002 \quad 0.902\end{array}$

(0.548) (1) 0.501

$\begin{array}{lll}0.321 & 0.268 & 0.432\end{array}$

$\begin{array}{lll}0.055 & 0.000 & 0.229\end{array}$

$\begin{array}{lll}0.630 & 1.000 \quad 0.486\end{array}$

Panel B - Changes in Audit Fees (t - (t-1))

\begin{tabular}{lrrrr} 
& \multicolumn{3}{c}{ Full Sample (n=409) } \\
& $\underline{\text { Mean }}$ & Median & Std. Dev \\
\cline { 5 - 5 } Deloitte_Switch & 0.188 & 0.000 & 0.391 \\
Chg_Log_Audit_Fees & $(0.216)$ & $(0.042)$ & 0.843 \\
Log_OtherandIT_Fees & 9.033 & 10.955 & 4.918 \\
Ratio_OtherandIT_Fees & 0.276 & 0.242 & 0.241 \\
Dummy_OtherandIT_Fees & 0.790 & 1.000 & 0.408 \\
Chg_Log_Size & $(0.01)$ & 0.02 & 0.39 \\
Chg_InvRec & 0.002 & 0.002 & 0.080 \\
Chg_ROA & $(0.000)$ & 0.006 & 0.627 \\
Chg_Leverage & 0.075 & 0.003 & 0.633 \\
Downgrade_Big4 & $(0.501)$ & $(1)$ & 0.501 \\
Chg_Segments & 0.116 & 0.000 & 0.350 \\
ICW & 0.061 & 0.000 & 0.240 \\
LossYear & 0.741 & 1.000 & 0.439
\end{tabular}

Deloitte Sample ( $n=77)$ $\underline{\text { Mean Median Std. Dev }}$

Non-Deloitte Sample ( $n=332)$ Mean Median $\underline{\text { Std. Dev }}$

$\underline{t}$-statistic

Wilcoxon Z

$\begin{array}{rrr}(0.250) & (0.083) & 0.886 \\ 9.724 & 11.225 & 4.241 \\ 0.292 & 0.237 & 0.233 \\ 0.857 & 1.000 & 0.352 \\ (0.02) & 0.02 & 0.28 \\ 0.002 & 0.003 & 0.073 \\ (0.008) & 0.001 & 0.372 \\ 0.029 & (0.004) & 0.189 \\ (0.506) & (1) & 0.503 \\ 0.153 & 0.000 & 0.361 \\ 0.026 & 0.000 & 0.160 \\ 0.636 & 1.000 & 0.484\end{array}$

$\underline{t}$-statistic

Wilcoxon Z

$\begin{array}{rrc}(0.012) & 0.077 & 0.956 \\ 8.838 & 10.908 & 5.041 \\ 0.269 & 0.239 & 0.243 \\ 0.770 & 1.000 & 0.421 \\ 0.03 & 0.04 & 0.53 \\ (0.005) & (0.001) & 0.104 \\ 0.036 & 0.019 & 0.698 \\ 0.080 & 0.018 & 0.652 \\ (0.557) & (1) & 0.498 \\ 0.337 & 0.318 & 0.460 \\ 0.098 & 0.000 & 0.298 \\ 0.793 & 1.000 & 0.406\end{array}$

$\begin{array}{rr}0.07 & 0.67 \\ 1.70 * & 0.86 \\ 0.74 & 1.03 \\ 1.96^{*} & 1.74 * \\ 0.66 & 1.46 \\ 0.82 & 1.29 \\ -1.16 & -0.65 \\ -0.30 & -0.48 \\ 0.14 & 0.14 \\ -0.27 & -0.45 \\ -1.37 & -1.17 \\ -2.66 * * * & -2.94 * * *\end{array}$

$-0.32$

0.60

0.94

1.61

$-0.23$

0.02

$-1.09$

$-0.56$

$-0.10$

1.15

$-1.43$

$-2.32 * *$

${ }^{*},{ }^{* *}$, and $^{* * *}$ denote two-tailed statistical significance at $10 \%, 5 \%$, and $1 \%$ respectively. See Appendix A for variable definitions. 
Table 7

Regression of the Change in Audit Fees on the interaction of the Probability of Deloitte Switch (vs. non-Deloitte Switch) and the Historical Reliance on Auditor-Provided Consulting Services

Panel A. Model (2a): Chg_Log_Audit_Fees $\mathbf{i}_{\mathbf{i} 2004-2002}=\alpha+\boldsymbol{B}_{1}\left(\right.$ ITandOther_Fees_01 $\left._{\mathbf{i}}\right)+$

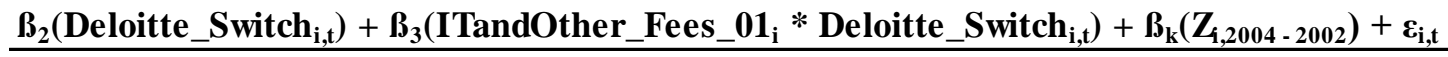

\begin{tabular}{|c|c|c|c|c|}
\hline \multirow{2}{*}{$\begin{array}{c}\text { Inde pendent } \\
\text { Variables }\end{array}$} & \multirow{2}{*}{$\begin{array}{l}\text { Pre dicted } \\
\text { Sign }\end{array}$} & \multicolumn{3}{|c|}{ Independent Variable of Interest } \\
\hline & & Log_Fees_O1 & Ratio_Fees_01 & Dummy_Fees_O1 \\
\hline \multirow[t]{2}{*}{ Intercept } & $?$ & -1.087 & -1.083 & -1.088 \\
\hline & & $(-5.64) * * *$ & $(-5.61) * * *$ & $(-5.64) * * *$ \\
\hline \multirow[t]{2}{*}{ ITandOther_Fees (Fees_01) } & $?$ & -0.013 & -0.356 & -0.101 \\
\hline & & $(-1.22)$ & $(-1.63)$ & $(-0.81)$ \\
\hline \multirow[t]{2}{*}{ Deloitte_Switch(Deloitte) } & $?$ & -0.558 & -0.270 & -0.584 \\
\hline & & $(-1.72) *$ & $(-1.24)$ & $(-1.72) *$ \\
\hline \multirow[t]{2}{*}{ Fees * Deloitte } & + & 0.054 & $\mathbf{0 . 8 0 3}$ & 0.649 \\
\hline & & $(1.87)^{*}$ & $(1.55)$ & $(1.78)^{*}$ \\
\hline \multirow[t]{2}{*}{ CHG_SIZE } & + & 0.267 & 0.264 & 0.268 \\
\hline & & $(2.73) * * *$ & $(2.68) * * *$ & $(2.74) * * *$ \\
\hline \multirow[t]{2}{*}{ CHG_INVREC } & + & 0.489 & 0.498 & 0.510 \\
\hline & & $(1.14)$ & $(1.15)$ & $(1.2)$ \\
\hline \multirow[t]{2}{*}{$C H G \_R O A$} & - & -0.023 & -0.022 & -0.025 \\
\hline & & $(-0.39)$ & $(-0.37)$ & $(-0.43)$ \\
\hline \multirow[t]{2}{*}{ CHG_LEVERAGE } & + & 0.083 & 0.083 & 0.082 \\
\hline & & (1.08) & (1.1) & $(1.05)$ \\
\hline \multirow[t]{2}{*}{ Chg_Big4 } & + & 0.923 & 0.935 & 0.916 \\
\hline & & $(9.52) * * *$ & $(9.36) * * *$ & $(9.81)^{* * *}$ \\
\hline \multirow[t]{2}{*}{ Chg_Segments } & + & 0.086 & 0.067 & 0.090 \\
\hline & & $(0.83)$ & $(0.66)$ & $(0.87)$ \\
\hline \multirow[t]{2}{*}{$I C W$} & + & 0.044 & 0.055 & 0.043 \\
\hline & & $(0.19)$ & $(0.24)$ & $(0.18)$ \\
\hline \multirow[t]{2}{*}{ LOSSYEAR } & + & -0.083 & -0.085 & -0.088 \\
\hline & & $(-0.66)$ & $(-0.67)$ & $(-0.69)$ \\
\hline Industry Fixed Effects & & Yes & Yes & Yes \\
\hline Year Fixed Effects & & Yes & Yes & Yes \\
\hline Adj. R-Squared & & 0.4148 & 0.4133 & 0.414 \\
\hline Observations & & 378 & 378 & 378 \\
\hline
\end{tabular}




\section{Table 7 (cont)}

Panel B. Model (2b): Chg_Log_Audit_Fees $s_{i, t-t-1}=\alpha+B_{1}\left(\right.$ ITandOther_Fees_01 $\left._{\mathrm{i}}\right)+$

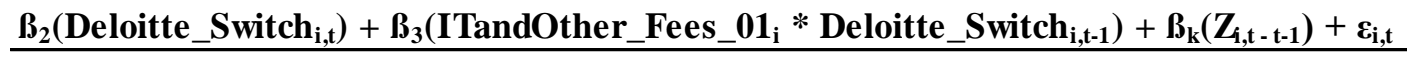

\begin{tabular}{|c|c|c|c|c|}
\hline \multirow{2}{*}{$\begin{array}{l}\text { Inde pendent } \\
\text { Variables }\end{array}$} & \multirow{2}{*}{$\begin{array}{l}\text { Predicted } \\
\text { Sign }\end{array}$} & \multicolumn{3}{|c|}{ Independent Variable of Inte rest } \\
\hline & & Log_Fees_O1 & Ratio_Fees_01 & Dummy_Fees_01 \\
\hline \multirow[t]{2}{*}{ Intercept } & $?$ & -0.395 & -0.404 & -0.391 \\
\hline & & $(-2.56)^{* *}$ & $(-2.58) * *$ & $(-2.52) * *$ \\
\hline \multirow[t]{2}{*}{ ITandOther_Fees_O1 (Fees_01) } & $?$ & -0.006 & -0.112 & -0.054 \\
\hline & & $(-0.63)$ & $(-0.6)$ & $(-0.45)$ \\
\hline \multirow[t]{2}{*}{ Deloitte_Switch(Deloitte) } & $?$ & -0.349 & -0.156 & -0.401 \\
\hline & & $(-1.49)$ & $(-0.86)$ & $(-1.64)$ \\
\hline \multirow[t]{2}{*}{ Fees_01*Deloitte } & + & 0.036 & 0.519 & 0.475 \\
\hline & & $(1.71)^{*}$ & $(1.3)$ & $(1.76)^{*}$ \\
\hline \multirow[t]{2}{*}{ CHG_SIZE } & + & 0.316 & 0.318 & 0.314 \\
\hline & & $(2.22) * *$ & $(2.25) * *$ & $(2.2)^{* *}$ \\
\hline \multirow[t]{2}{*}{$C H G_{-} I N V R E C$} & + & -0.102 & -0.146 & -0.068 \\
\hline & & $(-0.2)$ & $(-0.28)$ & $(-0.13)$ \\
\hline \multirow[t]{2}{*}{$C H G_{-} R O A$} & - & -0.004 & -0.006 & -0.005 \\
\hline & & $(-0.05)$ & $(-0.08)$ & $(-0.07)$ \\
\hline \multirow[t]{2}{*}{$C H G \_L E V E R A G E$} & + & 0.140 & 0.138 & 0.138 \\
\hline & & $(1.84)^{*}$ & $(1.81)^{*}$ & $(1.82)^{*}$ \\
\hline \multirow[t]{2}{*}{ Chg_Big4 } & + & 0.656 & 0.660 & 0.655 \\
\hline & & $(7.02)^{* * *}$ & $(6.96) * * *$ & $(7.19) * * *$ \\
\hline \multirow[t]{2}{*}{ Chg_Segments } & + & -0.010 & -0.022 & -0.008 \\
\hline & & $(-0.08)$ & $(-0.18)$ & $(-0.07)$ \\
\hline \multirow[t]{2}{*}{$I C W$} & + & -0.125 & -0.108 & -0.125 \\
\hline & & $(-0.48)$ & $(-0.41)$ & $(-0.48)$ \\
\hline \multirow[t]{2}{*}{ LOSSYEAR } & + & 0.029 & 0.031 & 0.026 \\
\hline & & $(0.26)$ & $(0.28)$ & $(0.23)$ \\
\hline Industry Fixed Effects & & Yes & Yes & Yes \\
\hline Year Fixed Effects & & Yes & Yes & Yes \\
\hline Adj. R-Squared & & 0.3540 & 0.352 & 0.3549 \\
\hline Observations & & 409 & 409 & 409 \\
\hline $\begin{array}{l}\text { This table presents OLS regressio } \\
\text { significance at } 10 \%, 5 \% \text {, and } 1 \% \mathrm{r} \\
\text { regressions, but are not tabulated } \\
\text { errors. See Table } 1 \text { for variable def }\end{array}$ & atistics (in $p$ & $\begin{array}{l}\text { l(2).*,**, and } \\
\text { fects for year an } \\
\text { ntheses) are bas }\end{array}$ & $\begin{array}{l}* * \text { denote two-tai } \\
\text { two-digit SIC cod } \\
\text { d on Huber-White }\end{array}$ & $\begin{array}{l}\text { statistical } \\
\text { are included in the } \\
\text { bust standard }\end{array}$ \\
\hline
\end{tabular}




\section{REFERENCES}

Ahmed, A., Rasmussen, S., Tse., S, 2008, Evidence on Audit Quality Differences Across Big N Audits: The Effect of Using an Industry Specialist Auditor on Cost of Equity, Working Paper.

Antle, R, Gordon, E, Narayanamoorthy, G, Zhou, L. 2006, The joint determination of audit fees, non-audit fees, and abnormal accruals, Review of Quantitative Finance and Accounting (2006) 27:235-266.

Artiach, T, D. Lee, D. Nelson, J. Walker, 2010, The Determinants of Sustainability Performance, Accounting \& Finance, Vol. 50, Iss. 1 (March): 31-51.

Ashbaugh, H., Lafond, R., and Mayhew, B., 2003, Do Nonaudit Services Compromise Auditor Independence? Further Evidence, The Accounting Review, Vol. 78, No. 3: 611-639

Ballas, A and Fafaliou, 2008, Market Shares and Concentration in the EU Auditing Industry: the effects of Andersen's Demise, Int Adv Econ Res, 14:485-497

Balsam, S., Krishnan, J., Yang, J.S. 2003. Auditor industry specialization and earnings quality. Auditing: A Journal of Practice \& Theory 22: 71-97

Barton, J. 2005. Who Cares about Auditor Reputation, Contemporary Accounting Research, Vol. 22, No. 3, Fall: 549-586

Beck, P. J.. T. J. Frecka. and I. Solomon. 1988. An empirical analysis of the relationship between MAS involvement and auditor tenure: Implications for auditor independence, Journal of Accounting Literature 7: 65-84.

Bell, T. B.. R. Doogar. and I. Solomon. 2008. Audit Labor Usage and Fees under Business Risk Auditing, Journal of Accounting Research 46 (4): 729-760.

Blouin, J., Grein, B.M., Roundtree, B.R. 2007. An analysis of forced auditor change: the case of former Arthur Andersen clients. The Accounting Review 82: 621-650

Burchell, B. and Wilkinson, F., 1997, Trust, Business Relationships and the Contractual Environment, Cambridge Journal of Economics, 21 (2): 217-237

Byrnes, Nanette, Why Deloitte Didn't Divide, Business Week Magazine: April 14, 2003

Byrnes, Nanette, The Comeback of Consulting: It's once more a huge business for Big Four auditors, thanks partly to Sarbanes-Oxley rules, Business Week Magazine: Sept 3, 2007

Causholli, M., W. R. Knechel and J. Macgregor. "An examination of the effect of nonaudit services and corporate governance on audit fees before and after passage of the Sarbanes-Oxley Act of 2002," Working paper, University of Florida, 2009

Chambers. D and J. Payne, 2008, Audit Quality and the Accrual Anomaly, Working Paper 
Chung, H., and S. Kallapur "Client importance, nonaudit services, and abnormal accruals." The Accounting Review October (2003): 931-955

Craswell, A., J. Francis, and S. Taylor. 1995. Auditor brand name reputations and industry specializations. Journal of Accounting \& Economics 20 3: 297-322.

Danos, P, J. W. Eichenseher, 1982, Audit Industry Dynamics: Factors Affecting Changes in Client-Industry Market Shares, Journal of Accounting Research 20 2: 604-616.

Dechow, P. R. Sloan, and A. Sweeney. 1995. Detecting earnings management. The Accounting Review 70: 193-225.

DeFond, M. L., Subramanyam, K.R., 1998. Auditor changes and discretionary accruals. Journal of Accounting and Economics 25, 35-67.

DeFond, M.., K. Raghunandan, and K. Subramanyam. 2002. Do non-audit service fees impair auditor independence? Evidence from going concern audit opinions. Journal of Accounting Research 40 4: 1247-1274.

Doogar R., N. Fargher, K.P. Hong, 2008, Audit Market Contestability in the Post-2002 Era, Working Paper

Dunn, K. A. and B. W. Mayhew. "Audit Firm Industry Specialization and Client Disclosure Quality." Review of Accounting Studies (March 2004): 35-58

Ettredge, M., C. Li, and S. Scholz. 2007. Audit fees and auditor dismissals in the Sarbanes-Oxley era. Accounting Horizons 21: 371-386

European Union (EU), 2010, European Commission Green Paper on Audit Policy, October 13

Ferguson. A., and D. Stokes. 2002. Brand name audit pricing, industry specialization and leadership premiums post-Big 8 and Big 6 mergers. Contemporary Accounting Research 19: 77-110.

Firth, M. 1997. The Provision of Non-Audit Services and the Pricing of Audit Fees, Journal of Business Finance \& Accounting 24 (3) \& (4): 511-525

Firth, M. 2002. Auditor-Provided Consultancy Services and their Associations with Audit Fees and Audit Opinions, Journal of Business Finance \& Accounting 29 (5) \& (6): 661-693

Francis, J, K. Reichelt, D. Wang, 2005, The Pricing of National and City-Specific Reputation for Industry Expertise in the U.S Audit Market, The Accounting Review Vol. 80, No. 1: 113-136

Frankel, R., M. Johnson, and K. Nelson. 2002. The relation between auditors' fees for non-audit services and earnings management. The Accounting Review 77 (Supplement): 71-105 
Fuller, K, J. Netter, and M. Stegemoller, 2002, What Do Returns to Acquiring Firms Tell Us? Evidence from Firms That Make Many Acquisitions, The Journal of Finance, vol. LVII, No. 4 AUGUST: 1763-1793

Geiger, M., and North, D., 2006, Does Hiring a New CFO Change Things? An Investigation of Changes in Discretionary Accruals, The Accounting Review, Vol 81, No 4:781-809

General Accounting Office (GAO). 2003. Public accounting firms: Mandated study on consolidation and competition. United States General Accounting Office (July).Washington, D.C.

. 2008. Audits of Public Companies: Continued Concentration in Audit Market For Large Public Companies Does Not Call For Immediate Action. United States General Accounting Office (January).Washington, D.C.

Gul, F, J. Tsui, 1997, A Test of the Free Cash Flow and Debt Monitoring Hypotheses: Evidence from Audit Pricing Journal of Accounting and Economics 24: 219-237

Gul, F, J. Tsui, D. S. Dhaliwal, 2006, Non-audit services, auditor quality and the value relevance of earnings, Accounting \& Finance 46: 797-817

Hillison, W., Kennelley, M., 1998 The Economics of Non-audit Services, Accounting Horizons, Sept. pp 32-40

Hogan, C. E., and D. C. Jeter. 1999. Industry specialization by auditors. Auditing: A Journal of Practice \& Theory 18: 1-17.

Hogan, C.E. and R.D. Martin. 2009. Risk Shifts in the Market for Audits: An Examination of Changes in Risk for "Second-Tier" Audit Firms. Auditing: A Journal of Practice and Theory 28 (November): 93-118.

Jensen, M.C., 1986, Agency Costs of Free Cash Flow, Corporate Finance, and Takeovers, The American Economic Review, Vol. 76, No. 2, pp. 323-329

Johnson, C., 2003, Clients Drop Deloitte After Its Consulting Decision, The Washington Post, April 9

Johnson, W. B., and T. Lys. 1990. The market for audit services. Journal of Accounting and Economics 12 (January): 281-308.

Kennedy, P. 1992. A Guide to Econometrics. Cambridge: MIT Press.

Kinney, W., Z. Palmrose, and S. Scholz. 2004. Auditor independence, non-audit services, and restatements: Was the U.S. Government Right? Journal of Accounting Research 42 3: 561-588.

Klasa, S, M. Stegemoller, 2007, Takeover Activity as a Response to Time-Varying Changes in investment Opportunity Sets: Evidence from Takeover Sequences, Financial Management, Summer: 19 - 43 
Knechel R. V. Naiker and G. Pacheco, 2007, Does Auditor Industry Specialization Matter? Evidence from Market Reaction to Auditor Switches, Auditing: A Journal of Practice \& Theory, Vol 26, No.1, May: 19-45

Knechel R. P. Rouse and C. Schelleman, 2009, A Modified Audit Productions Framework: Evaluating the Relative Efficiency of Audit Engagements, The Accounting Review, Vol 84, No.5: 1607-1638

Kohlbeck, M, B. Mayhew, P. Murphy, M. Wilkins, 2008, Competition for Andersen's Clients, Contemporary Accounting Research Vol. 25 No. 4, Winter: 1099-136

Kornish L., C. Levine, 2004, Discipline with Common Agency: The Case of Audit and Non-audit Services, The Accounting Review, Vol. 79, No. 1: 173-200.

Krishnan, G., M. S. Park, J. Vijayakumar, 2008, Does the Flight of Clients From The Big 4 to Second Tier Auditors Indiscate Lower Audit Quality, Working Paper

Krishnan, G., L. Sun, Q. Wang, 2010, Accruals Quality, Audit Fees, and Auditor Resignations, Working Paper

Krishnan, J. and J. Krishnan. 1997. Litigation risk and auditor resignations. The Accounting Review 72 (October): 539-560.

Landsman, W. R., K. K. Nelson, and B. R. Rountree. 2009, Auditor Switches in the Pre and Post-Enron Eras: Risk or Realignment? The Accounting Review, Vol 84, No 2: 531-558.

Larcker, D., Richardson, S., and Tuna, I., 2007, Corporate Governance, Accounting Outcomes, and Organizational Performance, The Accounting Review, Vol 82, No 4: $963-1008$

Lee, H. Y., 2002, What Determines Incumbent Auditors' Information Systems Design And Implementation Consulting Fees?, The Review of Business Information Systems, Vol. 6. No. 4: 1-12

Levitt, A. 2000. Renewing the covenant with investors. Remarks delivered at NYU Center for Law and Business, New York, NY, May 10.

Lim, C. Y. and H. T. Tan, 2008, Non-audit Service Fees and Audit Quality: The Impact of Auditor Specialization, Journal of Accounting Research, Vol. 46 No. 1 March: $199-246$

Lou, Y, F. Vasvari, 2009, Auditor Specialization and the Cost of Debt, Working Paper

Martin, K, 1996, The Method of Payment in Corporate Acquisitions, Investment Opportunities, and Management Ownership, The Journal of Finance. VOL. LI, NO. 4. Sept:1227-1246

Mitra, S. and M. Hossain, 2007, Ownership composition and non-audit service fees, Journal of Business Research, 60: 348-356 
Nagy A, W. Cenker, 2008, Auditor Resignations and Auditor Industry Specialization, Working Paper

Neal, T.L., Riley Jr, R.R. 2004. Auditor industry specialist research design. Auditing: A Journal of Practice \& Theory 23: 169-177.

Neu, D., 1991, Trust, contracting and the prospectus process, Accounting, Organizations and Society, Vol 16, Iss 3: 243-256

Palmrose, Z-V. 1986. The effect of non-audit services on the pricing of audit services: Further evidence. Journal of Accounting Research 24: 405-411.

Rama, D. V., and W. J. Read. 2006. Resignations by the Big 4 and the market for audit services. Accounting Horizons 20: 97-109.

Securities and Exchange Commission (SEC). Final Rule: Revision of the Commission's Auditor Independence Requirements, FRR No. 56. Washington, DC: SEC, 2000.

. Strengthening the Commission's Requirements Regarding Auditor

Independence. Final Rule Release No. 33-8183 (January 28, 2003), Washington, D.C.: Government Printing Office, 2003

Shu, S. Z. 2000. Auditor resignations: Clientele effects and legal liability. Journal of Accounting and Economics 29: 173-205

Simunic, D. 1980. The Pricing of Audit Services: Theory and Evidence, Journal of Accounting Research 18 1: 161-190

Simunic, D. 1984. Auditing, consulting, and auditor independence. Journal of Accounting Research 22 2: 679-702

Sullivan, M, 2006, Great Migration: How Recent Events Changed the Switching Behavior of Top-Tier Audit Clients, Working Paper

Treasury, U.S. Department of, Final Report of the Advisory Committee on the Auditing Profession to the U.S. Department of the Treasury: 2008.

U.S. Congress. (2002). Sarbanes-Oxley Act of 2002. H.R. 3763

Whisenant, S., S. Sankaraguruswamy, and K. Raghunandan. 2003. Evidence on the joint determination of audit and non-audit fees. Journal of Accounting Research 41 4: 721-744

White, H. 1980. A heteroskedasticity-consistent covariance matrix estimator and a direct test of heteroskedasticity. Econometrica: $817-838$

Wyatt, A. 2004, Accounting Professionalism-They Just Don’t Get It, Accounting Horizons, Vol. 18, Iss. 1: 45-53 